\title{
SEDMDESÁT LET ARCHEOLOGICKÝCH VÝZKUMŮ STŘEDOHRADIŠTNÍCH LOKALIT NA UHERSKOHRADIŠŤSKU A SOUČASNÝ STAV POZNÁNÍ TZV. OSTROVA SV. JIŘí
}

\author{
DANA MENOUŠKOVÁ
}

\begin{abstract}
Abstrakt: Od objevu a odborného výzkumu prvnich zděných velkomoravských staveb (resp. pozůstatků zdiva či negativù základů) ve Starém Městě „,Na Valách“ a ještě týž rok ve Starém Městě „Špitálkách“ uplynulo 70 let. Toto výroči se stalo podnětem k zamyšleni se nad stavem výzkumů i nad možnými perspektivami dalšiho vývoje. V pozadi prevratných objevů staroměstsko-uherskohradišstské aglomerace zůstalo jejich detailnějši vyhodnocení, ale i nivni poloha tzv. ostrova sv. Jiři (přibližně dnešni historické jádro Uherského Hradiště). Obraz aglomerace, který byl výzkumy během 50. až 80. let 20. století vytvořen, je novějšimi záchrannými aktivitami a prospekci pozvolna korigován.
\end{abstract}

Klíčová slova: středni doba hradištní - Staré Město - Uherské Hradiště - historie objevů -nové poznatky.

Seventy years of archaeological research into the Middle Hillfort sites in the Uherské Hradiště region and the current state of knowledge of the "Isle of St. George"

\begin{abstract}
Seventy years have passed since the discovery of and research into the first Great Moravian masonry structures (or the remains of masonry and the negatives of foundations) in Staré Mèsto - "Na Valách" and Staré Město - "Špitálky". This anniversary gave rise to reflections on the state of research and the possible perspectives of its further direction. The groundbreaking discoveries in the Staré Město and Uherské Hradišté agglomeration were not accompanied by detail assessment of the finds and did not involve the floodplain site of the "Isle of St. George" (approximately the present-day historical centre of Uherské Hradiště). The picture of the agglomeration created by research spanning the 1950s and 1980s has been gradually corrected, thanks to the latest rescue activities and prospection.
\end{abstract}

Key words: Middle Hillfort period - Staré Město - Uherské Hradiště - history of discoveries - new information.

\section{Historie objevování}

Objevy a výzkumy pozůstatků dvou středohradištních kostelů roku 1949 ve Starém Městě u Uherského Hradiště se staly významnými milníky, které nadlouho ovlivnily směřování archeologie střední doby hradištní, ale $\mathrm{i}$ řady archeologů. Za prvním $\mathrm{z}$ těchto objevů v zahradě Schilderova mlýna v lokalitě Staré Město „Na Valách“ stál učitel, posléze amatérský a nakonec profesionální archeolog Slováckého a od roku 1949 Moravského (dnes Moravského zemského) musea (muzea) Vilém Hrubý (1912-1985; obr. 1). Pod jeho vedením byl v lokalitě „Na Valách“ (obr. 2:4) na severu intravilánu Starého Města v roce 1948 obnoven terénní výzkum rozsáhlého a nálezově bohatého kostrového pohřebiště z období raného středověku, na němž byl následujícího

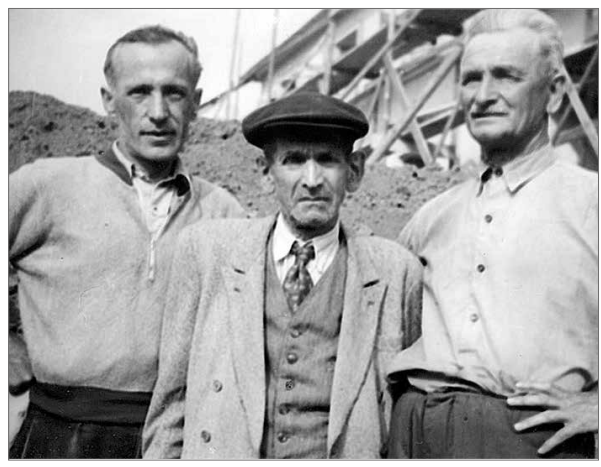

Obr. 1. Objevitelé středohradištních lokalit staroměstsko-uherskohradišt'ské aglomerace - V. Hrubý (první zleva), A. Zelnitius (uprostřed) a E. Lepka, Staré Město, 50. léta 20. století. Zdroj fotoarchiv Slováckého muzea.

Abb. 1. Entdecker der mittelburgwallzeitlichen Fundstätten der Siedlungsagglomeration Staré Město-Uherské Hradišstě - V. Hrubý (erster von links), A. Zelnitius (Mitte) und E. Lepka, Staré Město, fünfziger Jahre 20. Jahrhundert. Quelle Fotoarchiv des Museums der Mährischen Slowakei.

1 Př́ispěvek navazuje na stat' D. Frolíkové-Kaliszové v tomto čísle AH na stranách 785-807, zde také další informace k historii objevování. Cílem stati není detailní seznámení s dějinami bádání, $\mathrm{k}$ tomu odkazují zde citované práce (naposledy např. Galuška v tisku), ale uvedení do problematiky poznávání vývoje oblasti v době středohradištní a osvětlení dủležitých momentů, které nadlouho ovlivnily stav a rozdílnou úroveň poznání jednotlivých jejích částí. 


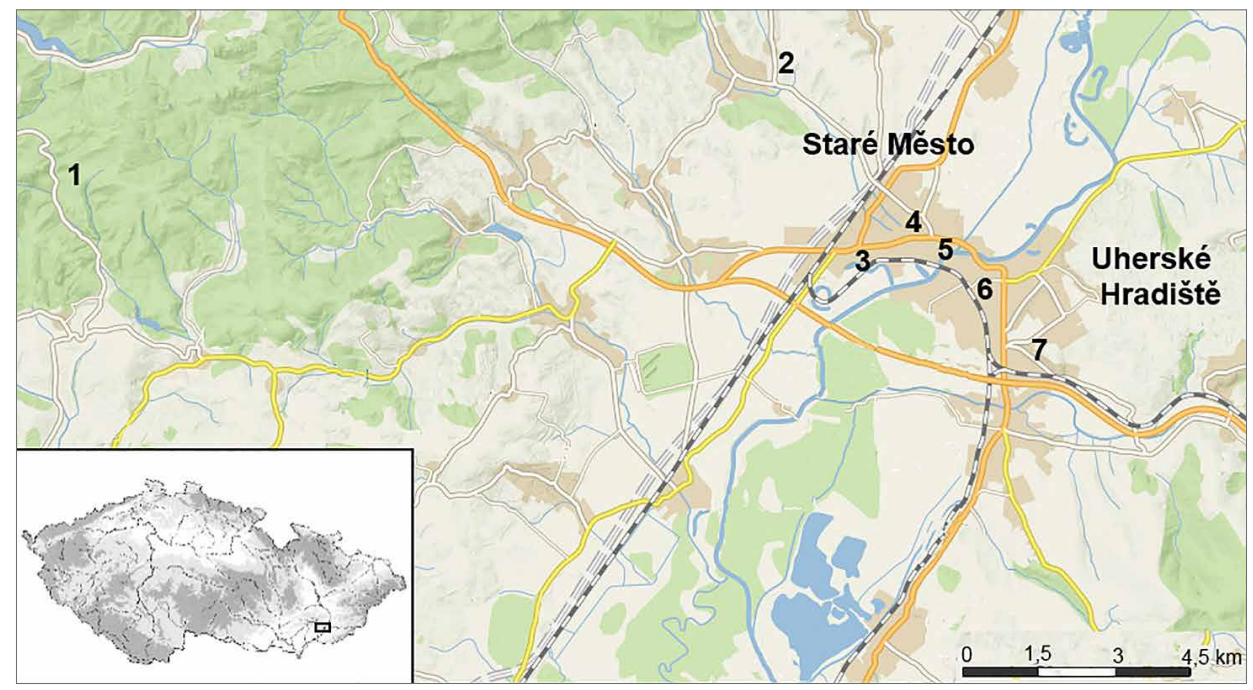

Obr. 2. Středohradištní lokality zmiňované v textu: 1 - Hradisko sv. Klimenta u Osvětiman; 2 - Modrá u Velehradu; 3 -Staré Město „Špitálky“; 4 - Staré Město „Na Valách“; 5 - Staré Město „Na Dědině“, kostel sv. Michala; 6 - tzv. ostrov sv. Jiří, dnes historické jádro Uherského Hradiště; 7 - Uherské Hradiště-Sady. Zdroj mapového podkladu https://mapy.cz/zakladni?x=17. $3878269 \& y=49.0693690 \& z=12 \& l=0$. Grafická úprava $D$. Menoušková.

Abb. 2. Im Text erwähnte mittelburgwallzeitliche Fundstätten: 1 - Burgstätte des HI. Clemens bei Osvětimany; 2 - Modrá bei Velehrad; 3 - Staré Město Lage „Špitálky“; 4 - Staré Město Lage „Na Valách“; 5 - Staré Město Lage „Na Dědině“, Kirche St. ichael; 6 - sog. St. Georgs-Insel, heutiger historischer Stadtkern von Uherské Hradiště; 7 - Uherské Hradiště-Sady. Quelle der Kartenvorlage https://mapy.cz/zakladni? $x=17.3878269 \& y=49.0693690 \& z=12 \& l=0$. Grafische Bearbeitung $D$. Menoušková.

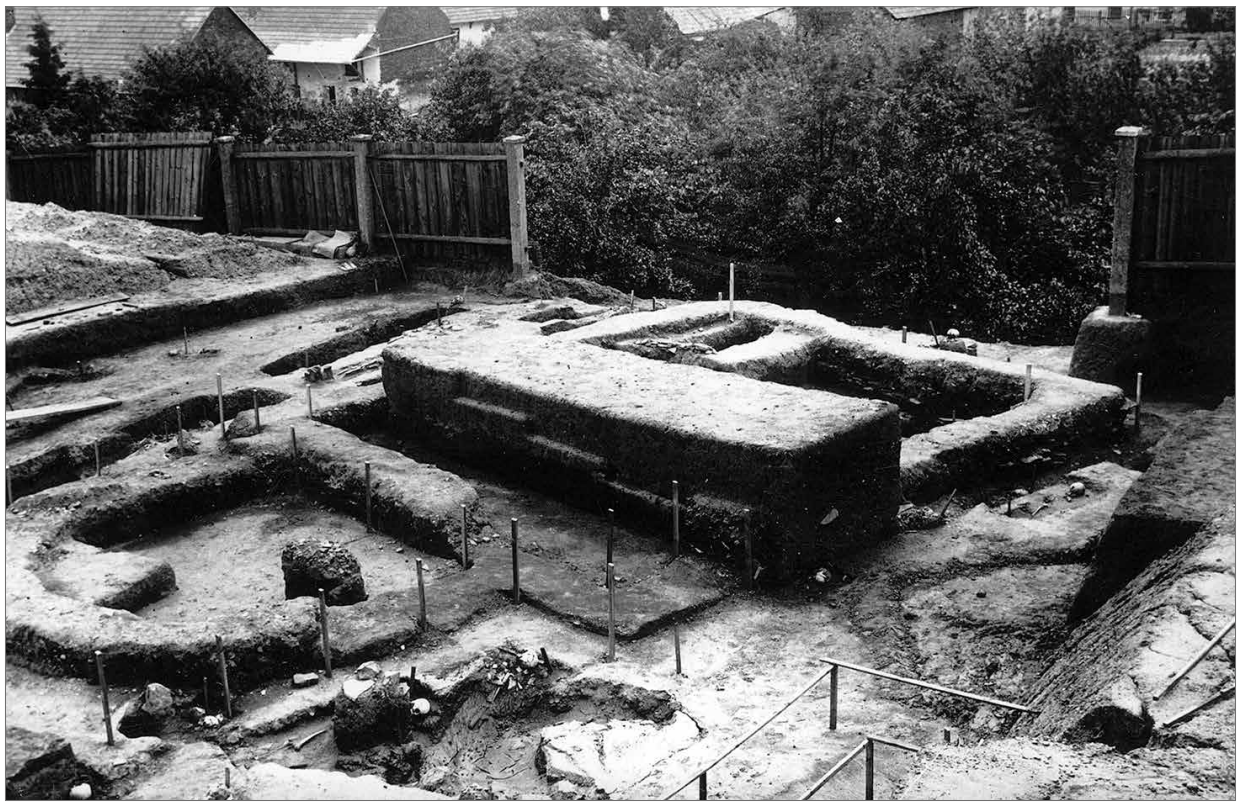

Obr. 3. Výzkum základů velkomoravského kostela a pohřebiště ve Starém Městě „Na Valách“, 1949. První odborně zkoumaný pozůstatek velkomoravského zdiva. Fotografie z roku 1949. Zdroj fotoarchiv Slováckého muzea.

Abb. 3. Freilegung des Fundaments der großmährischen Kirche und des Gräberfeldes in Staré Město Lage „Na Valách“, 1949. Erste fachgerecht untersuchte Überreste eines großmährischen Mauerwerks. Fotografie von 1949. Quelle Fotoarchiv des Museums der Mährischen Slowakei. 


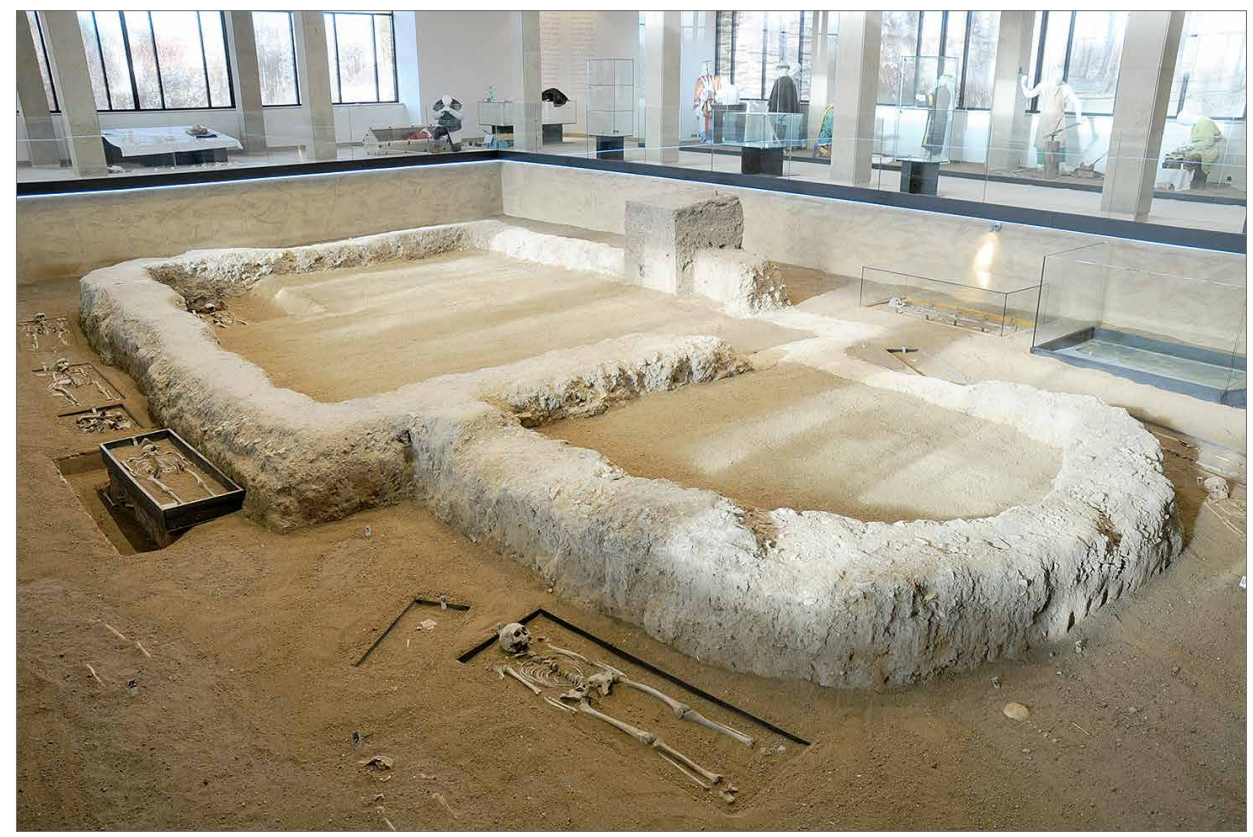

Obr. 4. Současný stav pozůstatků základů kostela a pohřebiště v lokalitě Staré Město „Na Valách“ v rámci instalace Památníku Velké Moravy. Foto L. Chvalkovský.

Abb. 4. Gegenwärtiger Zustand der Fundamentüberreste der Kirche und des Gräberfeldes an der Fundstätte Staré Město Lage „Na Valách“ im Rahmen der Installation des Denkmals Großmähren. Foto L. Chvalkovský.

roku (1949) odkryt již dříve indikovaný, ale dosud neobjevený základ (resp. negativ základu) jednolodního sálového kostela ze střední doby hradištní (obr. 3-4). Jednalo se o mimořádný objev, v rámci celého tehdejšího Československa to byly vůbec první odborně prozkoumané pozůstatky základu středohradištního kostela. Ještě týž rok na podzim (1949) byl pak za poněkud dramatických okolností zachráněn před odtěžením plytký negativ základu další velkomoravské stavby - kostela ve Starém Městě „Špitálkách“ (obr. 2:3), tentokrát zásluhou vedoucího Státního archeologického ústavu v Brně Josefa Poulíka (1910-1998; k historii objevování viz také GaluškaVaškových-Menoušková 2016, 25-63). Lokalita ležící na štěrkopískové terase nad meandrem řeky Moravy byla zkoumána v letech 1949-1950,„záchranným výzkumem“ a před úplným odtěžením se podařilo zachránit alespoň její severní polovinu (více Poulík 1950, 12-22; Hrubý 1965b, 92-95, 96; 196-197). Tedy severní polovinu kostela a část pohřebiště čítající 46 hrobů, 47 pohřbů (srovnej Hrubý 1965b, 93). Jen malá část z kostrového pohřebiště, resp. hrobové výbavy byla zachráněna př̀i započetí samotné těžby, tedy ještě před a při porušení základů kostela. Vedle zmíněného prvenství záchranného výzkumu drží staroměstské „Špitálky“ bohužel ještě jeden primát. Jako jediné se nacházejí v prostředí absolutně neadekvátním významu lokality. V terénu rekonstruované základy jsou totiž obklopeny průmyslovými areály, které značně devalvují naleziště jako takové i jakékoli snahy po uvedení této národní kulturní památky $\mathrm{v}$ širší povědomí (obr. 5). Na objevování pozůstatků zdiv dvou středohradištních kostelů ve Starém Městě, jakož i na následných archeologických výzkumech z 50.-80. let 20. století v oblasti Uherskohradišt'ska a jejich interpretaci se do značné míry podepsaly jak jsoucí politické poměry a preference, tak osobní averze některých badatelů. ${ }^{2}$ Extenzivní a v mnohém ojedinělé odkryvy ve Starém Městě

2 K tomu podrobněji př́spěvek D. Frolíkové-Kaliszové (2020,785-807), který ilustruje zákulisí některých objevů. 


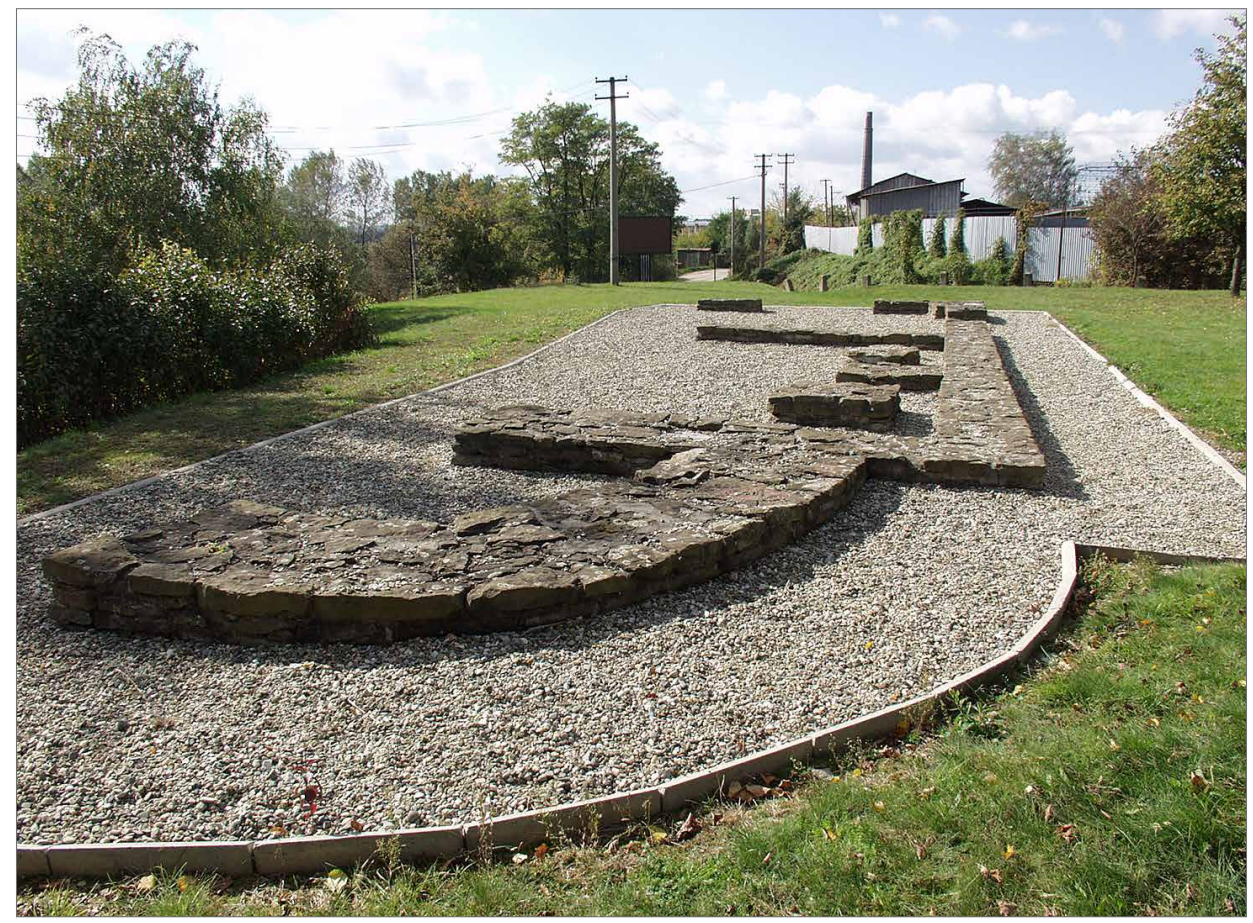

Obr. 5. Současný stav lokality Staré Město „Špitálky“ objevené J. Poulíkem v rámci záchranného výzkumu na podzim roku 1949. Ještě před výzkumem byla lokalita z jižní části odbagrovaná. Foto L. Chvalkovský.

Abb. 5. Gegenwärtiger Zustand der von J. Poulík im Rahmen einer im Herbst 1949 in Staré Město durchgeführten Rettungsgrabung entdeckten Fundstätte „Špitálky“. Noch vor der Grabung wurde die Fundstätte vom südlichen Teil her freigebaggert. Foto L. Chvalkovský.

na sebe poutaly výjimečnou pozornost, což se podepsalo na poznávání středohradištních počátků jiné, velmi blízké lokality: tzv. ostrova sv. Jiří, tedy historického jádra dnešního Uherského Hradiště. V konečném důsledku tak došlo k rozdělení sfér zájmů: Staré Město se od té doby stalo doménou Viléma Hrubého (potažmo Moravského zemského musea/muzea), Uherské Hradiště především Roberta Snášila (Slováckého muzea).

Výše zmíněné unikátní objevy by ovšem nebyly možné bez předchozích průzkumů, výkopů a sběrů amatérských archeologů a zájemců o obor, kteří působili v regionu a položili tak základy dalšího poznání.

Již od 80. let 19. století se lokalita ve Starém Městě „Na Valách“ těšila zájmu amatérských archeologů Františka Myklíka, Ignáce Tkáče a Martina Kř́že. Výzkumné aktivity vygradovaly s příchodem Antonína Zelnitia (zvláště po roce 1924), původně učitele a posléze amatérského archeologa, který se stal od roku 1929 vedoucím záchranného výzkumu prováděného zde Státním archeologickým ústavem v Praze (obr. 1). Právě se Zelnitiem (1876-1957) je spojeno rozpoznání významu lokality, její chronologické zařazení i počátky objevování rozsáhlého velkomoravského pohřebiště a dokumentace nezřídka honosného hrobového inventáře i sídlištních objektů. Na něj po obnovení výkopových prací roku 1948 navázal Vilém Hrubý a hned následující rok učinil onen zásadní objev negativní výplně základových rýh sálového kostela v poloze Staré Město „Na Valách“.

Objevování základů velkomoravských církevních staveb na Uherskohradišt'sku mělo nicméně svoji předehru již na počátku 20. století. V roce 1911 srovnával profesor bohoslovecké 


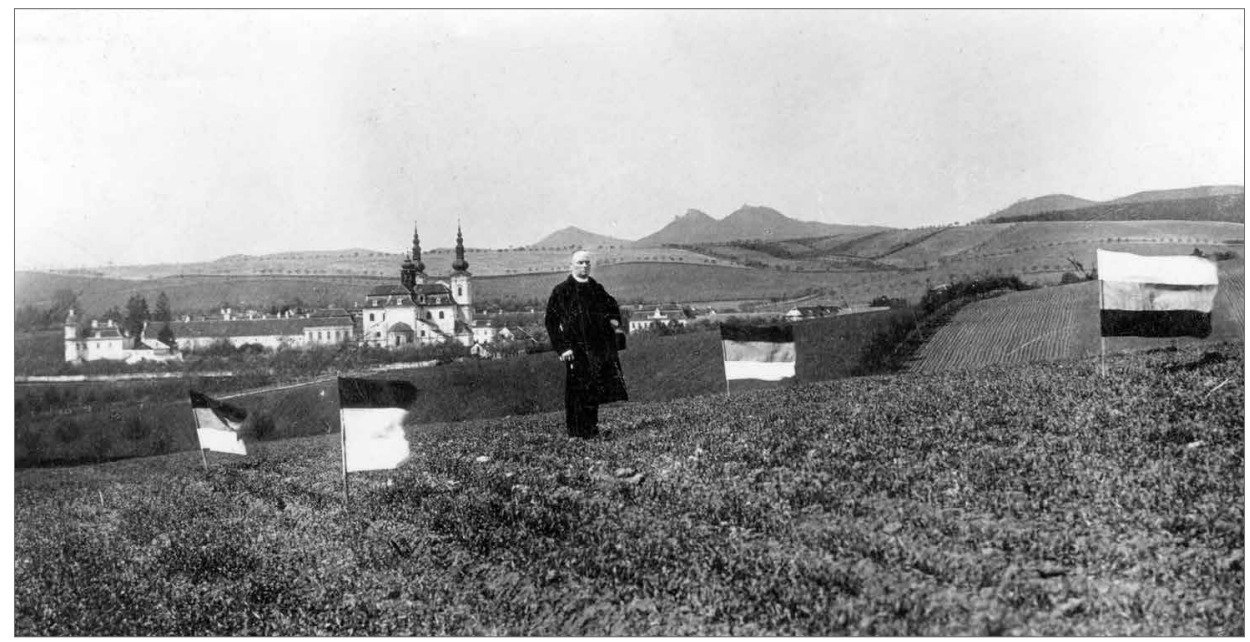

Obr. 6. Jan Nevěřil, objevitel základů velkomoravského kostela v Modré u Velehradu (1911) na lokalitě. Zdroj fotoarchiv Slováckého muzea.

Abb. 6. Jan Nevěřil, der Entdecker des Fundaments der großmährischen Kirche in Modrá bei Velehrad (1911) an der Fundstätte. Quelle, Fotoarchiv des Museums der Mährischen Slowakei.

fakulty v Olomouci Jan Nevěřil základy kostelíka v Modré u Velehradu (vzdušnou čarou asi 4 km od Starého Města) s podobným půdorysem kostela sv. Kateřiny na Tetíně (Nevěřil 1940, 76-80) a v důsledku této analogie datoval i kostelík v Modré do doby po př́ichodu cyrilometodějské misie (obr. $2: 2 ; 6)$. S poukazem na písemné prameny ztotožňoval stavbu se zmínkami o kostele sv. Jana u Velehradu. ${ }^{3} \mathrm{O}$ potvrzení velkomoravského původu kostela, který dnes patří k nejraněji datovaným velkomoravským církevním stavbám (před polovinou 9. století, Cibulka 1958; souhrnně Hrubý 1965b 198-202; popř. Galuška-Vaškových-Menoušková 2016, 87-95, zvl. 89), se zasadil až revizní výzkum z let 1953-1954 (obr. 7-8). Vilém Hrubý (1965b, 95-97; 198-202) jím zvláště na základě rozboru hrobového inventáře 37 kostrových hrobů zdejšího pohřebiště potvrdil časné datování stavby.

Ještě hlouběji sahají počátky amatérských aktivit u jiné archeologické lokality na Uherskohradišt'sku, která je spojená se stále velmi silnou cyrilometodějskou tradicí a s neutuchajícím zájmem veřejnosti. Jde o jednu z nejhůře poznaných, byt' dlouhodobě zkoumaných lokalit: hradisko sv. Klimenta u Osvětiman ${ }^{4}$ (obr. 2:1). Hradisko leží v jižní části Chřibů, asi 25 km západně od Uherského Hradiště, na rozhraní katastrů Osvětiman a Moravan, v nadmořské výšce asi 400-461 m, na protáhlé zčásti opevněné ostrožně trojúhelného tvaru.

Silná a dosud živá cyrilometodějská tradice vztahující se k hradisku lokalitu bohužel nenávratně poškodila. Řada historických terénů byla zničena a jen stěží se rekonstruuje původní obraz hradiska v dobách Velké Moravy. Lokalita a její nejbližší okolí čelí různým amatérským výzkumům a výkopům již od 18. století (souhrnně viz Hrubý 1959, 19-59, 65-70; Menoušková 2001, 159-184) a v lidové tradici bývala spojována s místem, kde byly uloženy ostatky

3 Jde o listiny Přemysla Otakara I. z let 1202 a 1228. Podle zfalšované, ale věcně správné listiny z roku 1202 kupuje moravský markrabě Vladislav Jindřich pro účely kláštera statek, na jehož pozemcích již v době donace stál prázdný a pustý kostelík sv. Jana. Znovu je kostel sv. Jana uváděn v privilegiu z roku 1228, kdy bere Přemysl Otakar I. velehradský klášter pod královskou ochranu (Hrubý 1965b, 97). V době budování cisterciáckého komplexu na počátku 13. století tak modranský kostelík patrně plnil funkci provizoria. Definitivní zánik kostela je kladen před konec 17. století, kdy po požáru velehradského kláštera v roce 1681 bylo použito k jeho obnovení i stavebního materiálu z kostela sv. Jana.

$4 \mathrm{O}$ hradisku se poprvé dočteme v písemném prameni z roku 1358: V něm je olomouckým biskupem Janem Očkem z Vlašimi potvrzena předchozí donace moravského markraběte Jana Jindřicha, který místo s již existující kaplí sv. Klimenta (nejasného stáři) daruje brněnským augustiniánům-poustevníkům. Definitivní zánik osídlení na lokalitě je možné klást na počátek 16. století. 


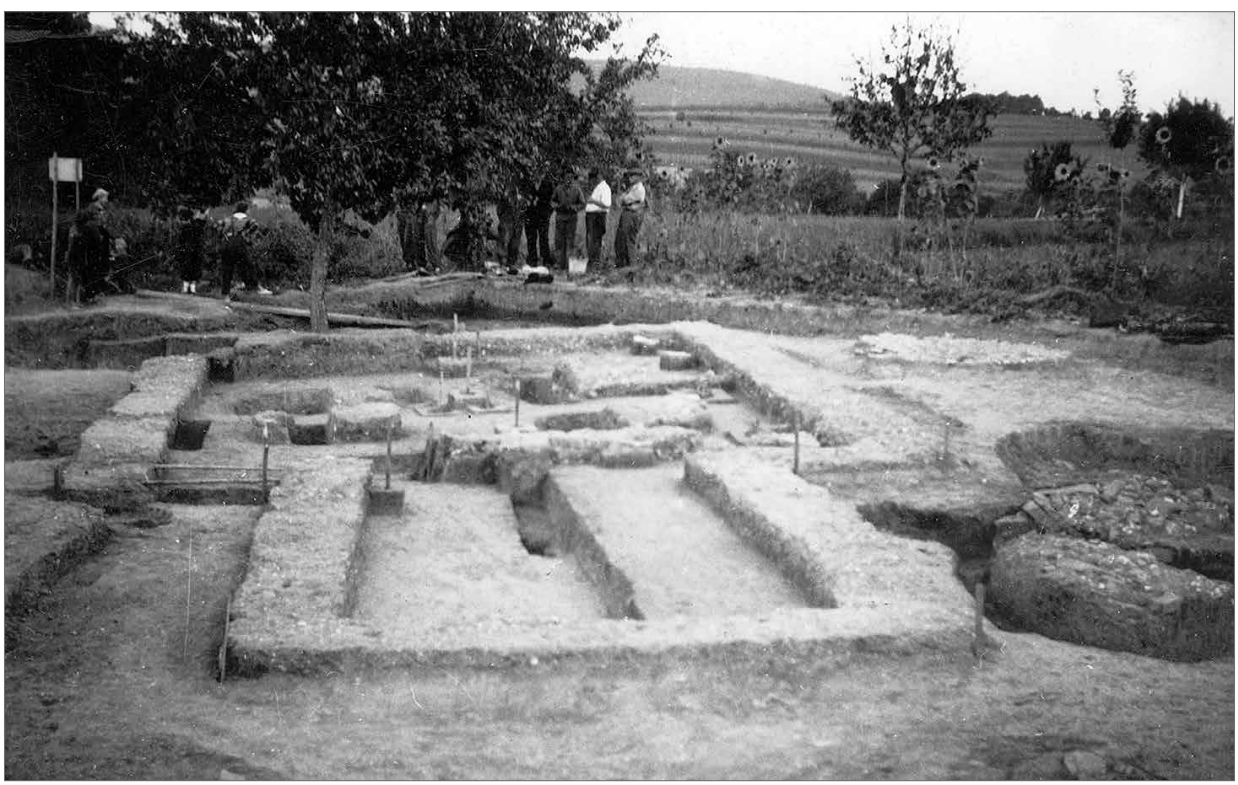

Obr. 7. Revizní výzkum V. Hrubého na lokalitě Modrá v 50. letech 20. století. Zdroj fotoarchiv Slováckého muzea.

Abb. 7. Revisionsgrabung von V. Hrubý an der Fundstätte Modrá in den fünfziger Jahren des 20. Jahrhunderts. Quelle Fotoarchiv des Museums der Mährischen Slowakei.

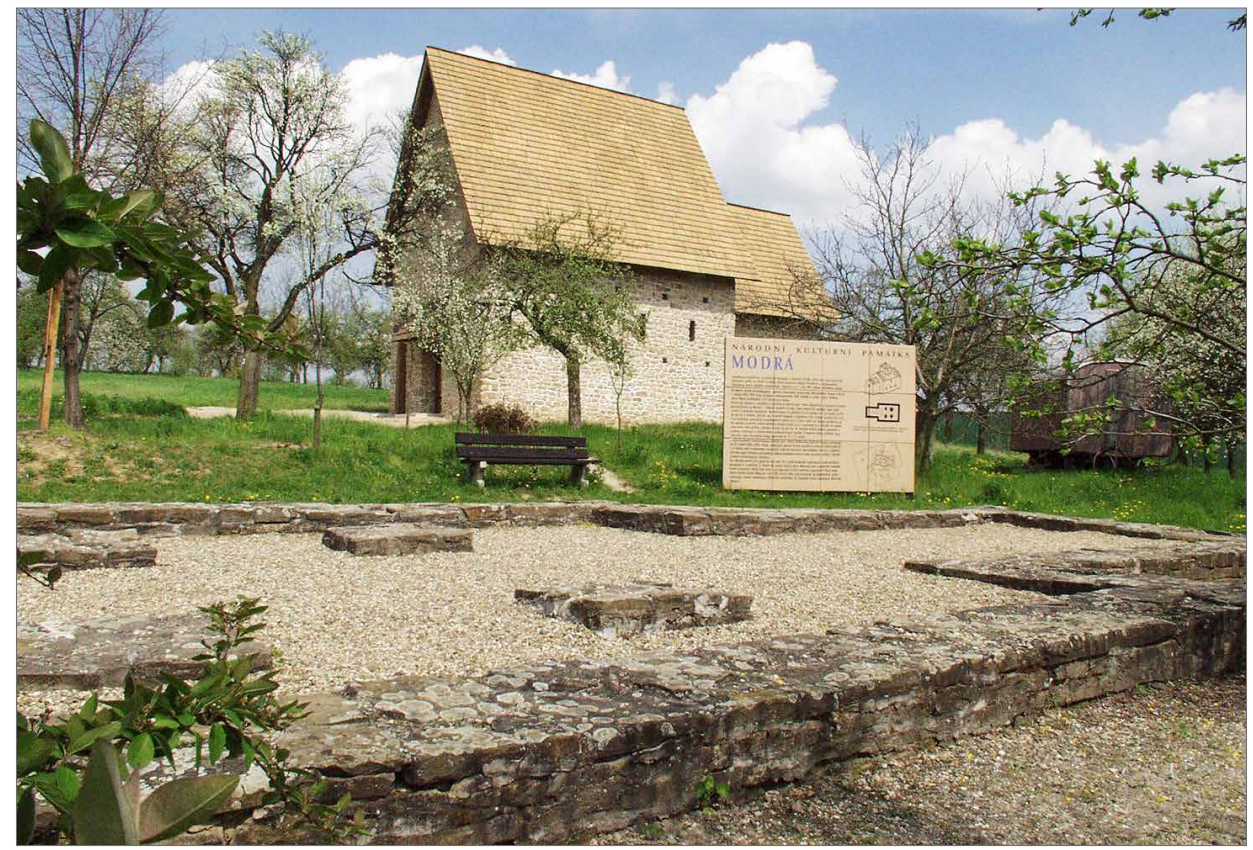

Obr. 8. Současný stav lokality Modrá u Velehradu v pozadí s hypotetickou rekonstrukcí kostela v rámci areálu tamního archeoskanzenu. Foto L. Chvalkovský.

Abb. 8. Gegenwärtiger Zustand der Fundstätte Modrá bei Velehrad im Hintergrund mit hypothetischer Rekonstruktion der Kirche im Rahmen des Areals des dortigen archäologischen Freiluftmuseums. Foto L. Chvalkovský. 


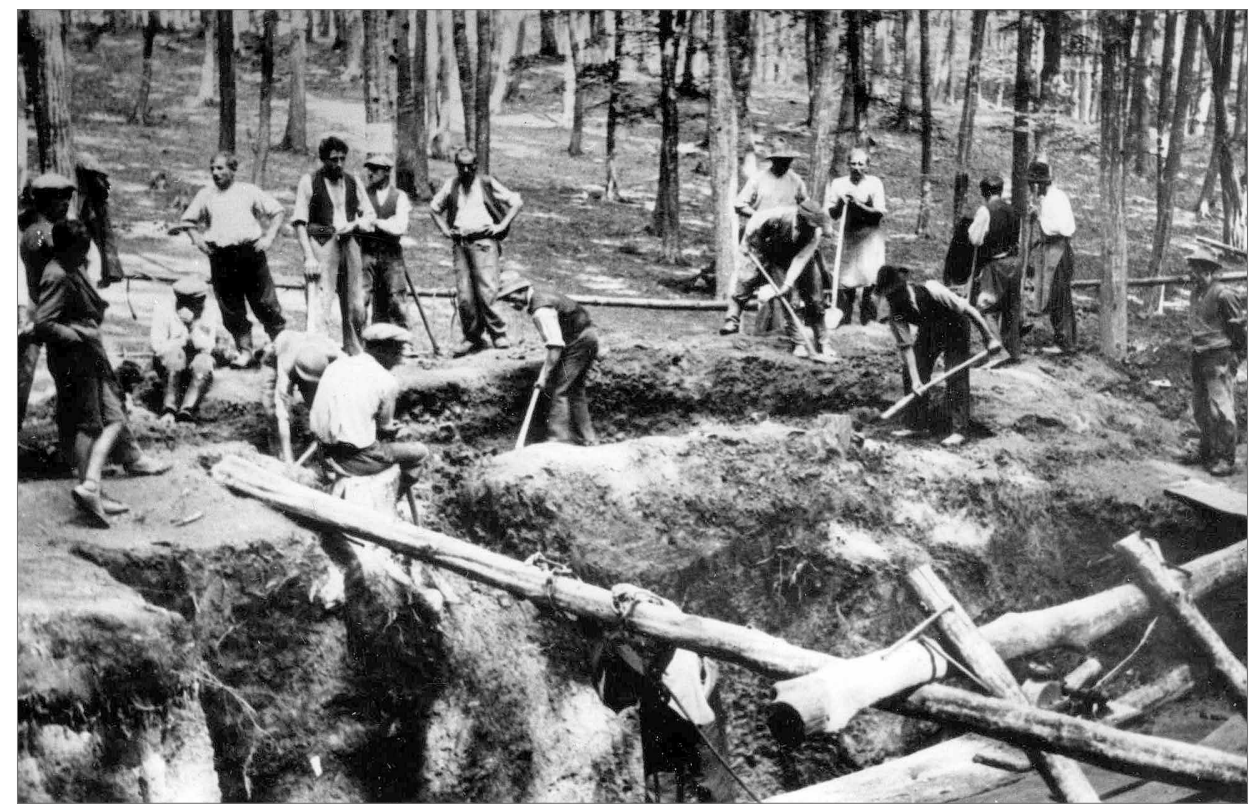

Obr. 9. Osvětimany, trat' „Hroby“ v blízkosti hradiska sv. Klimenta, patrně 1932. Hloubení až 5 m hlubokých jam, v nichž byl dle K. Maštalířové hledán hrob sv. Metoděje. Zdroj fotoarchiv Slováckého muzea.

Abb. 9. Osvětimany, Lage „Hroby“ in der Nähe der Burgstätte des HI. Clemens, offenbar 1932. Aushebung von bis zu 5 m tiefen Gruben, in denen laut K. Maštalířová das Grab des HI. Method gesucht wurde. Quelle Fotoarchiv des Museums der Mährischen Slowakei.

sv. Metoděje. Na to, kde je na hradisku Metoděj pohřben, byla dokonce v lednu 1931 dotázána stigmatizovaná Terezie Neumannová. O objev podvržených náhrobních kamenných desek v trati Hroby (obr. 9) v letech 1932-1933 (severovýchodně od hradiska) se „zasloužila“ domkářka z nedaleké Stupavy Klementina Maštalířová (např. Sklenář 1977, 158-165).

Značný posun ve znalostech o lokalitě přinesly až poválečné vědecké aktivity. Výzkum Moravského muzea v Brně pod vedením V. Hrubého roku 1958 (1965a, 147-149) a V. Ondruše v letech 1961-1962 (1965, 112-115), podnícený zájmem místních obyvatel, otevřel vážnou a dodnes neuzavřenou diskusi nad stárím zde nalezených základů kostela a jeho stavebním vývojem (k tomu Menoušková 2001). Přítomnost malty indikující existenci stavby s omítnutými stěnami již v 9. století vedla V. Ondruše k dataci nejstarší části kostela (původně půlkruhovitého závěru) do velkomoravského období. V rozporu s tímto chronologickým zařazením však amatérská sonda historiků umění z roku 1976 (Konečný-Kudělka-Malinová-Samek 1977/1978, 41) shledala alespoň v místě sondy zdivo závěru svázané s gotickým opěrákem a spolu s předstouplým zdivem základové podnože vedla tato zjištění $\mathrm{k}$ jednoznačnému závěru, že zdivo závěru kostela souvisí až se stavebními aktivitami augustiniánů.

Datování, ale ani charakter jednotlivých stavebních fází kostela na hradisku sv. Klimetna nejsou stále uspokojivě objasněny. S ohledem na nové poznatky ohledně masivního využití dřeva při stavbách zvláště některých velkomoravských zděných kostelů (souhrnně Poláček 2014, 87-91; viz též Poláček-Maříková-Kubková 2010) a s přihlédnutím k dosavadním poznatkům a fragmentárnosti nálezů z akropole hradiska sv. Klimenta je třeba zvažovat i hypotézu existence stavby kombinující v různé míře obě stavební komponenty (dřevo i kámen; srovnej též Macháček 2014, 186). Problematické se z hlediska interpretace jeví i předchozí terénní zásahy. Jednou z mála cest, jak naše znalosti o hradisku posunout dál, je tak využití nedestruktivních archeologických metod, 


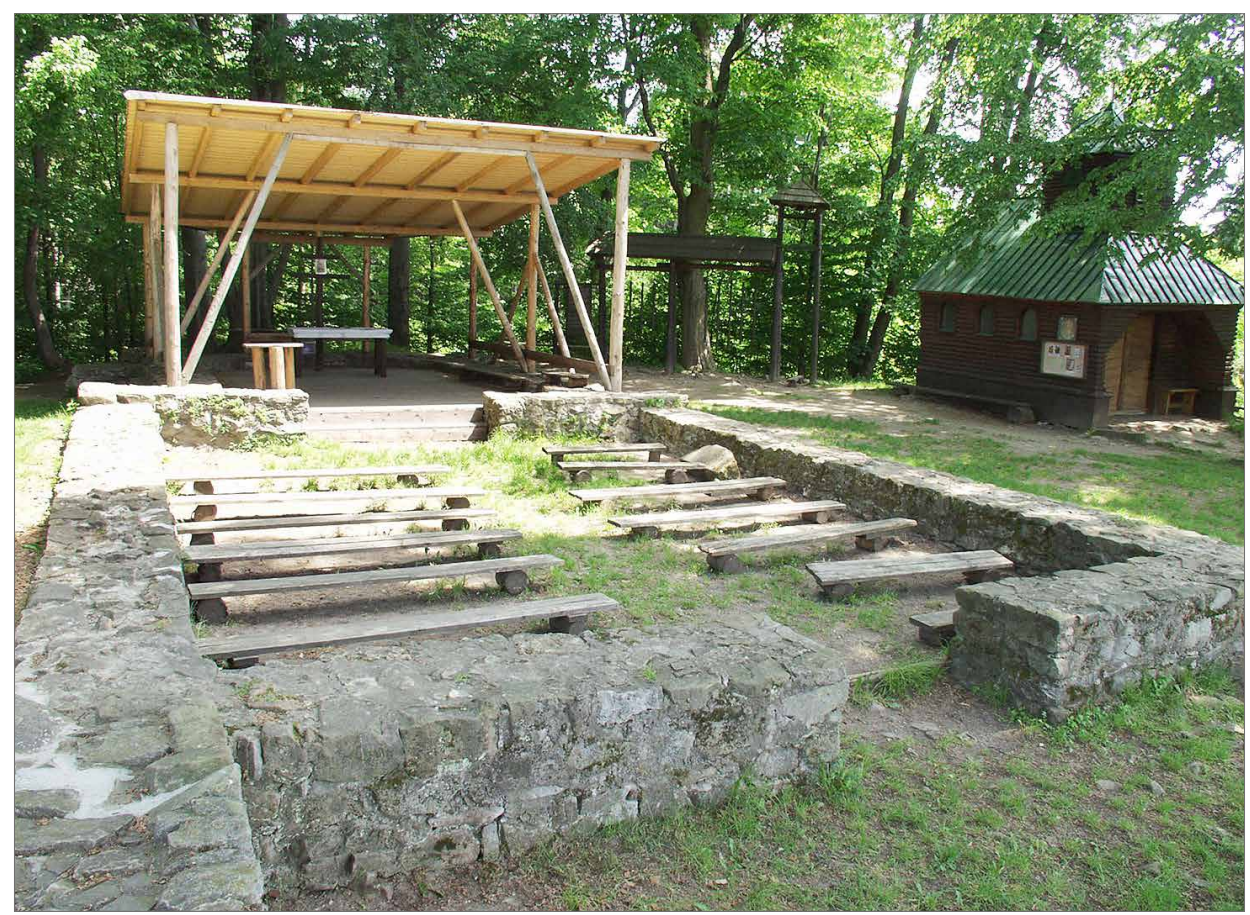

Obr. 10. Akropole hradiska sv. Klimenta, nelegální úpravy v prostoru vrcholové plošiny v 90. letech 20. století. Foto L. Chvalkovský.

Abb. 10. Akropolis der Burgstätte des HI. Clemens, illegale Herrichtung im Bereich des Höhenplateaus in den neunziger Jahren des 20. Jahrhunderts. Foto L. Chvalkovský.

například geofyzikálního průzkumu a dalších především přírodovědných analýz, a to ve spolupráci se soukromými vlastníky pozemku, který je dnes z větší části zalesněný (obr. 10). ${ }^{5}$

Podobně jako v př́ípadě hradiska sv. Klimenta u Osvětiman chybí kritické, interdisciplinární (např. Macháček a kol. 2007) či minimálně moderní pramenné zpracování s využitím možností např́iklad geofyzikálních a dalších přírodovědných metod (např. Látková 2019; Dresler a kol. 2010; Witen 2006; Udphuay-Paul-Everett-Warden 2010; viz též níže) také dalším středohradištním lokalitám staroměstsko-uherskohradišt'ské aglomerace. Zakonzervování stavu, v jakém byly tyto a další ${ }^{\prime}$ středohradištní lokality na přelomu 40. až 50. a 60. let 20. století objeveny (byt' pod značným politickým tlakem a preferencemi) a prvotně publikovány, výmluvně ilustruje i fakt, že s výjimkou Uherského Hradiště-Sadů (Galuška 1996; Galuška a kol. 2019; obr. 2:7; 11-12) a částečně lokality Modrá „Na Díle“7 nedošlo u žádné z nich k souhrnnému či reviznímu zpracování a nebyly využity analytické možnosti současné archeologie a spolupracujících prŕírodovědných oborů - např́iklad s cílem představit tyto významné lokality z interdisciplinárního hlediska.

\footnotetext{
5 Stejně jako se na hradisku nesmazatelně podepsalo jeho nesnadné archeologické objevování, tak jej poznamenalo také vyřazení ze seznamu Národních kulturních památek a změna statusu vlastnictví. Lokalita byla zvláště v 90 . letech 20 . století vystavena obrovskému náporu návštěvníků v rámci náboženských poutí, ale i necitlivým stavebním zásahům. V posledních letech se o rehabilitaci pošramocené pověsti ve spolupráci s odbornou veřejností snažilo Občanské sdružení Přátel hradiska sv. Klimenta.

6 Zmínit je třeba ještě výzkum základů velkomoravské rotundy v interiéru kostela sv. Michala ve Starém Městě v roce 1962. Nedaleko stavby byl posléze V. Hrubým identifikován základ další stavby patrně středohradištního stáři (palác?).

7 Publikační výstup z lokality Uherské Hradiště-Sady je součástí rozsáhlejš̌́ho projektu komplexně zpracovávajícího lokalitu, resp. pohřebiště, včetně některých př́rodovědných analýz (např. analýz DNA). Situace trati Modrá „Na Díle“ byla naposledy sumarizována v rámci průvodce tamním archeoskanzenem, viz Galuška-Vaškových 2006; dále pak zprávami reflektujícími jednotlivé sezóny novodobých archeologických výzkumů lokality (např. Chrástek 2010; Vaškových 2014).
} 


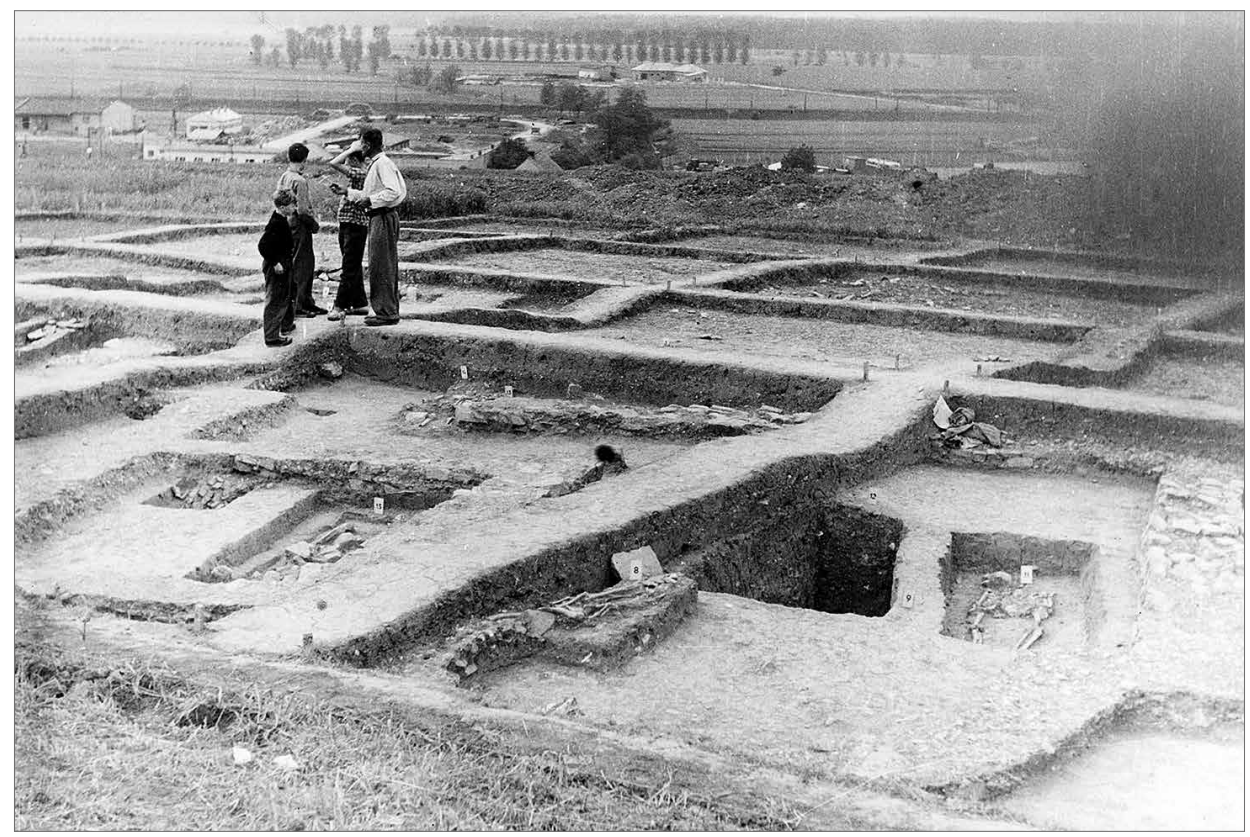

Obr. 11. Výzkum souboru staveb a pohřebiště raně křest’anského areálu klášterního charakteru v Uherském Hradišti-Sadech $v$ letech 1959-1964. Lokalita patří $k$ nejlépe poznaným středohradištním nalezištím regionu. Zdroj fotoarchiv Slováckého muzea.

Abb. 11. In den Jahren 1959-1964 in Uherské Hradiště-Sady durchgeführte Freilegung eines Komplexes von Bauten und eines Gräberfeldes eines frühchristlichen Areals klösterlichen Charakters. Die Fundstätte zählt zu den am besten erforschten mittelburgwallzeitlichen Fundstätten der Region. Quelle Fotoarchiv des Museums der Mährischen Slowakei.

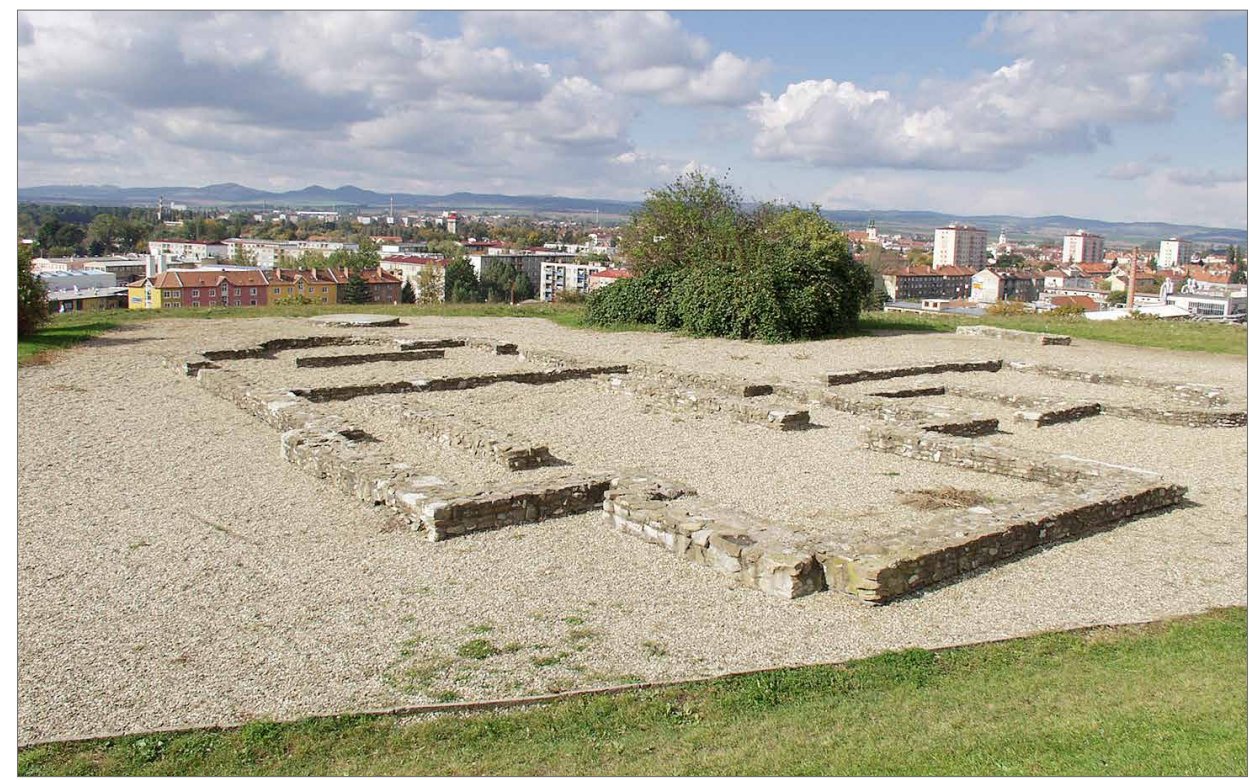

Obr. 12. Současný stav raně křest’anského areálu klášterního charakteru v Uherském Hradišti-Sadech. Foto L. Chvalkovský.

Abb. 12. Gegenwärtiger Zustand des frühchristlichen Areals klösterlichen Charakters in Uherské Hradiště-Sady. Foto L. Chvalkovský. 


\section{Středohradištní osídlení v prostoru tzv. ostrova sv. Jiří}

V pozadí převratných objevů a extenzivních výzkumů staroměstsko-uherskohradišt'ské aglomerace zůstalo jak jejich detailnější vyhodnocení vůbec, tak nivní poloha tzv. ostrova sv. Jiří (přibližně dnešní historické jádro Uherského Hradiště). Zpřesnění našeho pohledu na osídlení Uherského Hradiště je možné až po systematickém zpracování a vyhodnocení výzkumů, ${ }^{8}$ zvláště výzkumů posledních let. Významnou roli přitom sehrávají i výsledky geofyzikální prospekce.

Tyto postupy dokážou dobře dokumentovat raně středověké sídelní aktivity pod hustou městskou zástavbou, ale i dynamické změny př́rodních podmínek tzv. ostrova sv. Jiří během střední doby hradištní. Jedná se především o zanášení a zasypávání starých říčních koryt a nárůst a patrně i výraznější stratifikaci osídlení (nejnověji například Bartík-Chrástek 2018). Zmíněná situace se mimo jiné odráží i v nálezech torz a destrukcí zděných architektur a dalších stavebních prvků (srovnej např. Dresler-Vágner 2013; Menoušková-Dresler-Pelikán 2019, 81-94).

Přesto mají naše znalosti o raně středověké sídelní struktuře na levobřeží řeky Moravy v prostoru dnešního historického jádra Uherského Hradiště stále neúplný charakter a jen s různou mírou úspěchu se daří dílčí závěry sumarizovat (srovnej např. Menoušková-Dresler-Pelikán 2019, 81-94; Galuška 2014; Škrdla-Vaškových-Galuška 2007). Jedná se přitom o významné středohradištní centrum 8. a 9. století s řadou dokladů raně středověkých kamenných architektur (destrukce zdiva, nálezy malty, částečně zachované nadzemní zdivo středohradištního stáŕí, srovnej obr. 13).

Již roku 1982 při kopání šachty kašny (Snášil-Procházka 1982; 1984, 64) a v roce 1983 při liniovém výkopu (Snášil-Novotný 1985, 72-73) se na nynějším Masarykově náměstí podařilo zachytit a následně ověrit pozůstatky zdiva z lomového pískovce a malty velkomoravského stáŕí (obr. 13:2-3). Stavba byla patrně opatřena litou maltovou podlahou. Pozitiv zdiva byl uložen v základové rýze, hloubené do předvelkomoravské vrstvy. Nejzachovalejší ze tř́i zachycených reliktů bylo zdivo široké $80 \mathrm{~cm}$, v neporušeném stavu bylo sledováno do výšky $60 \mathrm{~cm}$, narušené pokračovalo do výšky $95-110$ cm (obr. 14). Podle zdvojené destrukční vrstvy s hlinitou mezivrstvou, provázenou keramickými i kovovými nálezy, soudil R. Snášil, že k zániku stavby došlo ještě během střední doby hradištní.

V souvislosti s anomálií zachycenou v těsné blízkosti stavby (základy zdiva rotundy?), zaměřenou novějším geofyzikálním výzkumem je pak možné hypoteticky zvažovat profánní charakter středohradištního objektu/zdiva zjištěného v 80. letech.

Geofyzikální průzkum, při němž byla kruhová anomálie (rotunda?) objevena, proběhl v prostoru Masarykova náměstí v roce 2012 (obr. 13:1, 15). Jeho primárním cílem bylo pod úrovní současného terénu zachytit pozůstatky středověkého kostela sv. Jiří, zrušeného na konci 18. století. Vedle zachycených základů kostela byla v místě jeho presbytáře zaznamenána nicméně ještě anomálie interpretovaná jako možná starší stavba - rotunda. Hypoteticky by se mohlo jednat o stavbu (kapli svatého Jiř̌i ${ }^{9}$ ) zmiňovanou v písemném prameni roku 1257, která v prostoru nově zakládaného města stála ještě před jeho vysazením. S ohledem na absenci jiného než středohradištního a posléze až stř̌edověkého osídlení v prostoru historického jádra je tedy možné zvažovat středohradištní stáří zachycené anomálie (souhrnně Menoušková 2013; Dresler-Vágner 2013). Případné zdivo bylo pod někdejším gotickým presbytářem kostela zjištěno v hloubce větší než $2,5 \mathrm{~m}$ a jevilo se jako anomálie mající tvar kruhu. Takto naměřený průměr dosahoval přibližně $6,5 \mathrm{~m}$. V př́padě potvrzení měření by bylo nanejvýš logické, aby nad starší stavbou, at' již velkomoravského nebo jiného stáří, byla postavena mladší stavba tak, aby nejposvátnější místo kostela zůstalo prostorově

\footnotetext{
$8 \mathrm{~K}$ problematice absence nálezových zpráv z extenzivních výzkumů a nedostatečné evidence některých nálezových souborů z Uherského Hradiště, které vzaly za své při zaplavení depozitáře, viz prŕíspěvek D. Frolíkové-Kaliszové (2020, 785-807).

9 Nejstarší zmínku o svatyni s patrociniem sv. Jiří v prostoru dnešního Uherského Hradiště nalezneme v první písemné zprávě o nově vznikajícím městě: ,ad insulam, in qua sita est capella sancti Georgii“ (CDB V/1, 218-220, č. 135). Pochází z listiny Přemysla Otakara II. z roku 1257. Zmiňuje se v ní, že: „,na ostrově, na kterém stoji kaple sv. Jiři“, bylo shledáno nejvhodnější místo k založení města. Kapli svatojiřského zasvěcení nahradil po polovině 15 . století kostel. Z pramenů není zřejmé, zda původní kaple byla povýšena na kostel a stala se základem této stavby, nebo byl gotický kostel stejného zasvěcení postaven samostatně. Diagonální orientace kostela vůči ploše náměstí a jinak pravidelné středověké zástavbě nicméně naznačuje, že stavba chrámu se přizpůsobovala nějakému stavebnímu omezení.
} 


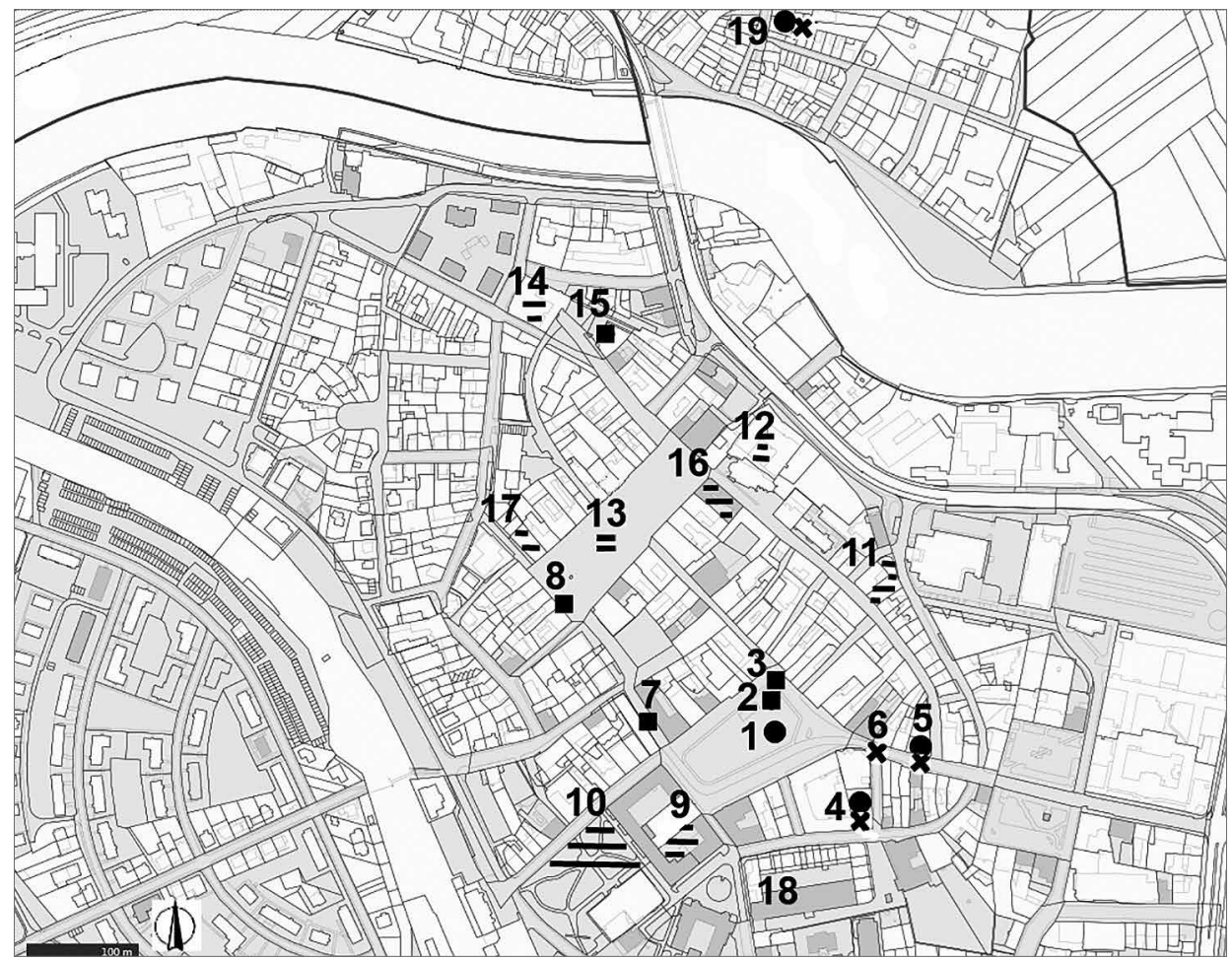

Obr. 13. Nálezové situace raně stř̌edověkého stáří vynesené do katastrální mapy Uherského Hradiště. 1 - hypotetická kaple sv. Jiří (Masarykovo náměstí) na základě geofyzikálního průzkumu; 2-3 - pozůstatky zdiva v prostoru kolem kašny na Masarykově náměstí; 4-5 - pozůstatky zdiva a kostrových hrobủ (Hradební SPT Telecom a Havlíčkova); 6 - kostrový hrob v ulici Rủžové; 7 - destrukce kamenného objektu v ulici Protzkarově; 8 - srubové stavby na nároží Mariánského náměstí; 9-10 - sídlištní vrstvy v místě nádvoří dnešní Reduty a v přilehlém parku; 11 - sídlištní vrstvy na nároží ulic Hradební a Krátké; 12 - sídlištní vrstvy v prostoru rajského dvora františkánského kláštera; 13 - souvrství na místě kašny (Mariánské náměstí); 14 - sídlištní vrstvy na nádvoří Galerie Slováckého muzea; 15 - sídlištní vrstvy a základy stavby na Otakarově ulici; 16 - sídlištní vrstvy na místě Základní umělecké školy nároží Františkánské ulice a Mariánského náměstí; 17 - sídlištní vrstvy na Mariánském náměstí; 18 - hypotetická dřevěná palisáda (př́stupová cesta ?) na Hradební ulici; 19 - pozůstatky zdiva kostela a kostrové hroby v části Rybárny, Luční ulice; •- pozůstatky zdiva sakrálních (?) staveb, —- pozůstatky zdiva bez bližšího určení; × - hrob, hroby; 三- sídlištní vrstva. Grafická úprava D. Menoušková.

Abb. 13. In der Katasterkarte von Uherské Hradiště eingetragene frühmittelalterliche Fundsituationen. 1 - hypothetische St. Georgskapelle (Masaryk-Platz) anhand einer geophysikalischen Untersuchung; 2-3-Mauerwerksüberreste im Bereich um den Brunnen auf dem Masaryk-Platz; 4-5 - Überreste eines Mauerwerks und von Skelettgräbern (Hradební-Str. [SPT Telecom] und Havlíčkova-Str.); 6 - Skelettgrab in der Rủžová-Str.; 7 - Zerstörung eines Steinobjektes in der Protzkarova-Str.; 8 - Blockbauten an der Ecke des Marienplatzes; 9-10 - Siedlungsschichten im Hof der heutigen Redoute und im daran angrenzenden Park; 11 - Siedlungsschichten an der Ecke der Straßen Hradební und Krátká; 12 - Siedlungsschichten im Bereich des Paradieshofs des Franziskanerklosters; 13 - Schichtenfolge an der Stelle des Brunnens (Marienplatz); 14 - Siedlungsschichten im Hof der Galerie des Museums der Mährischen Slowakei; 15 - Siedlungsschichten und Fundament eines Baus in der Otakarova-Str.; 16 - Siedlungsschichten an der Stelle der Kunstgrundschule Ecke Františkánska-Str. und Marienplatz; 17 - Siedlungsschichten auf dem Marienplatz; 18 - hypothetische Holzpalisade (Zugangsweg ?) in der Hradební-Str.; 19 - Mauerwerksüberreste einer Kirche und Skelettgräber im Stadtteil Rybárny, Luční-Str.; • - Mauerwerksüberreste von sakralen (?) Bauten, @ - Mauerwerksüberreste ohne nähere Bestimmung; × - Grab, Gräber; 三- Siedlungsschicht. Grafische Bearbeitung D. Menoušková.

zachováno. To by také vysvětlovalo nestandardní orientaci kostela (diagonálně vůči náměstí), který se tak mohl rozšśřit pouze západním směrem, téměř až k uliční čáře. Anomálii zjištěnou geofyzikálním měřením je nutno v budoucnu ověřit archeologickým výzkumem, což není v husté městské zástavbě a s ohledem na potřeby města úkol právě nejjednodušší.

Do závěru stř̌edohradištního období je datována také nedostavěná, na maltu zděná, patrně sakrální stavba tvaru křiže (?), která byla zjištěna archeologickým výzkumem při výstavbě telekomunikační budovy SPT Telecom (obr. 13:4, 16), vymezené ulicemi Hradební a Růžová 


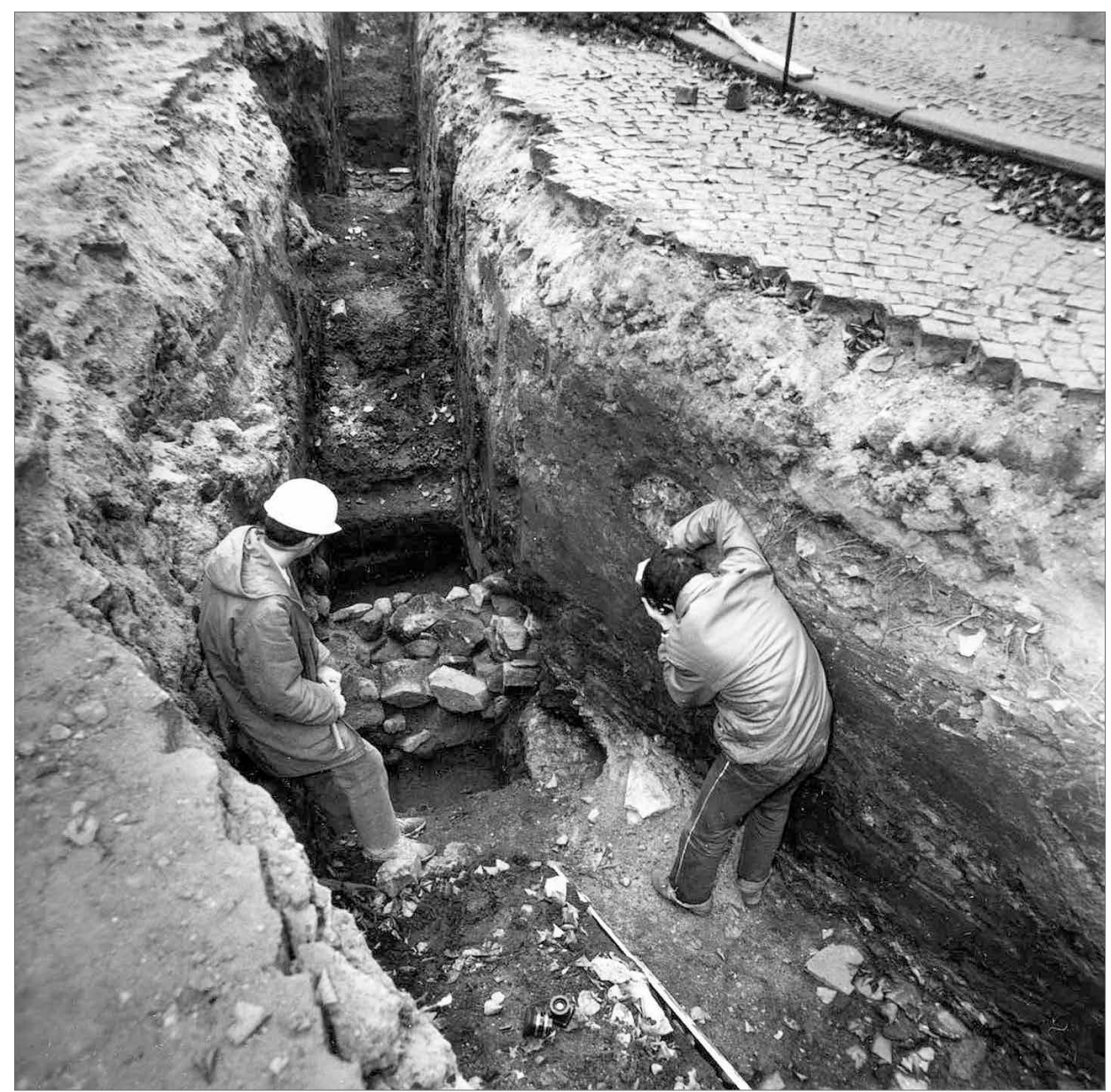

Obr. 14. Terénní snímek z výzkumu z roku 1983 se základovým zdivem a základovou rýhou stř̌edohradištního stáŕí. Na svrchní část zdiva navazuje destrukční vrstva malty, kamenů a hlíny (na snímku patrné v popředí). Foto L. Chvalkovský.

Abb. 14. Geländeaufnahme von der Grabung aus dem Jahr 1983 mit Fundamentmauerwerk und Fundamentrinne mittelburgwallzeitlichen Alters. An den oberen Teil des Mauerwerks schließt eine Zerstörungsschicht von Mörtel, Steinen und Lehm an (auf der Aufnahme im Vordergrund sichtbar). Foto L. Chvalkovský.

(Kohoutek-Procházka 1993; 1997, 252), již v 90. letech 20. století. V rámci téhož výzkumu byl zachycen stratigraficky současný příkop o šíri $8 \mathrm{~m}$ a hloubce až $2,5 \mathrm{~m}$, který středohradištní stavbu respektoval. Existenci pohřebiště a u něho situovaného kostela indikuje vedle kostrového hrobu bez milodarů z této polohy také minimálně jeden velkomoravský hrob (patrně ale alespoň dva hroby; podle šperku ženské, obr. 13:6) z nedaleké ulice Růžové, z polohy naproti historickému domu U Labutě (Hanák 1932, 7; 1933, 5; Zelnitius 1933, 14; 1946, 101; Snášil-Procházka 1981b, 12; Galuška 2001, 133; Hrubý 1965b, 100 - uvádí pět hrobů). Další obdobně datovaný hrob bez milodarů je znám z blízké Havlíčkovy ulice, tzv. dům manželů Arnoštových (obr. 13:5). Zde byla zjištěna i destrukce kamenné stavby středohradištního stáří (Vitula 1997, 254-256; ČižmářGeislerová-Unger 2000, 234). ${ }^{10}$ 


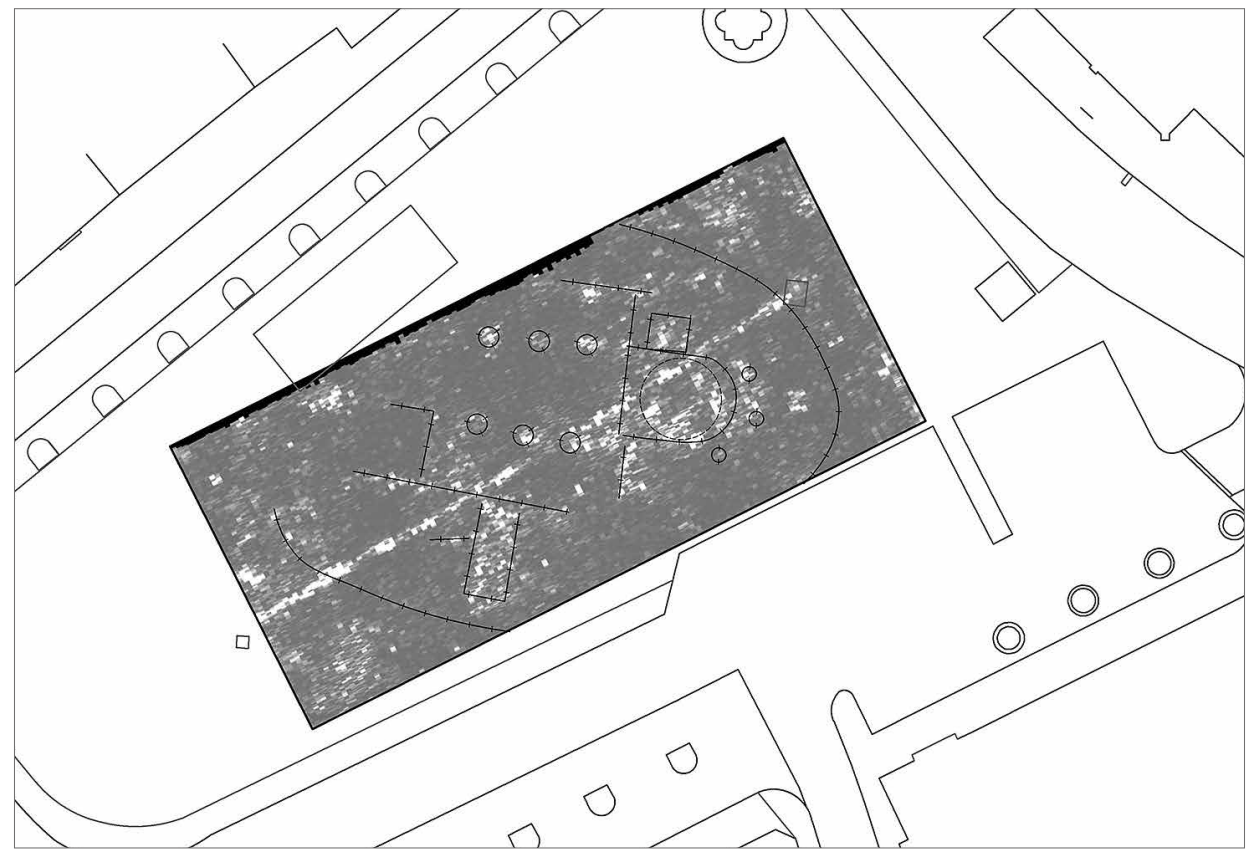

Obr. 15. Geofyzikálním měřením identifikovaná anomálie v místech presbytáře kostela sv. Jiří (zrušeného na konci 18. století), který nahradil v písemném prameni k roku 1257 zmiňovanou kapli svatého Jiří na dnešním Masarykově náměstí. Na snímku na základě změřených anomálií vynesené základy kostela i starší stavby v místě závěru kostela. Patrné také recentní zásahy (diagonálně - elektrické sítě). Nevýrazná anomálie má tvar kruhu o prủměru přibližně 6,5 m. Podle Dresler-Vágner 2013.

Abb. 15. Durch geophysikalische Messung identifizierte Anomalien an den Stellen des Chorraums der (Ende des 18. Jhdts. beseitigten) St. Georgskirche, welche die in schriftlichen Quellen zum Jahr 1257 erwähnte St. Georgskapelle auf dem heutigen Masaryk-Platz ersetzte. Auf der Aufnahme anhand der gemessenen Anomalien eingetragenen Fundamente der Kirche und älterer Bauten an der Stelle des Kirchenabschlusses. Sichtbar sind auch rezente Eingriffe (diagonal - Stromnetz). Die undeutliche Anomalie hat die Form eines Kreises mit einem Durchmesser von ungefähr 6,5 m. Nach Dresler-Vágner 2013.

Část kamenného zdiva středohradištního stáří stavěného na maltu a deset kostrových hrobů s pozůstatky dvanácti pohřbených (včetně např. dětského kostrového hrobu s ostruhou s ploténkami či dalších hrobů s doklady železného kování rakví) objevil R. Snášil (Snášil-Krut’a-Stloukal 1994, 115-147; 1995, 73-78) při záchranném výzkumu pod hustou zástavbou městské části Rybárny, Luční ulice (obr. 13:19, 17). Jedna z hypotéz sakrální stavbu ztotožňuje s velkomoravskou svatyní sv. Klimenta. R. Snášil ji pro středověkou fázi města dává do souvislosti se zmínkou o špitální kapli (Snášil 2001, 180-186).

Při výčtu pozůstatků zdiva velkomoravského stáří je třeba připomenout nález z roku 1983, kdy byly na nároží nynějšího Mariánského náměstí (Snášil-Novotný 1985, 73) doloženy základy zdiva srubové stavby, jejíž kameny byly spojovány vápennou maltou. Stavba byla datována do mladšího velkomoravského horizontu. Na témže místě se podařilo zachytit i pozůstatky další velkomoravské kamenné architektury a objektů, a to ve formě koncentrace vápenných malt a keramiky (obr. 13:8).

Zásadní vhled do sídelních aktivit na severním okraji historického jádra přinesl předstihový výzkum na ulici Otakarově (viz příspěvek D. Frolíkové-Kaliszové) v místě demolovaných domů přiléhajících k městskému opevnění (obr. 13:15), parcelní čísla 129 a 130 (např. Snášil-Procházka 1981a; Snášil-Novotný 1985, 71; Frolíková-Kaliszová 2001, 115-121). Výzkum klasifikoval pro prostředí Uherského Hradiště dodnes platný modus dvou horizontů středohradištního osídlení: předvelkomoravský a velkomoravský. Propojením archeologických situací s poznatky 


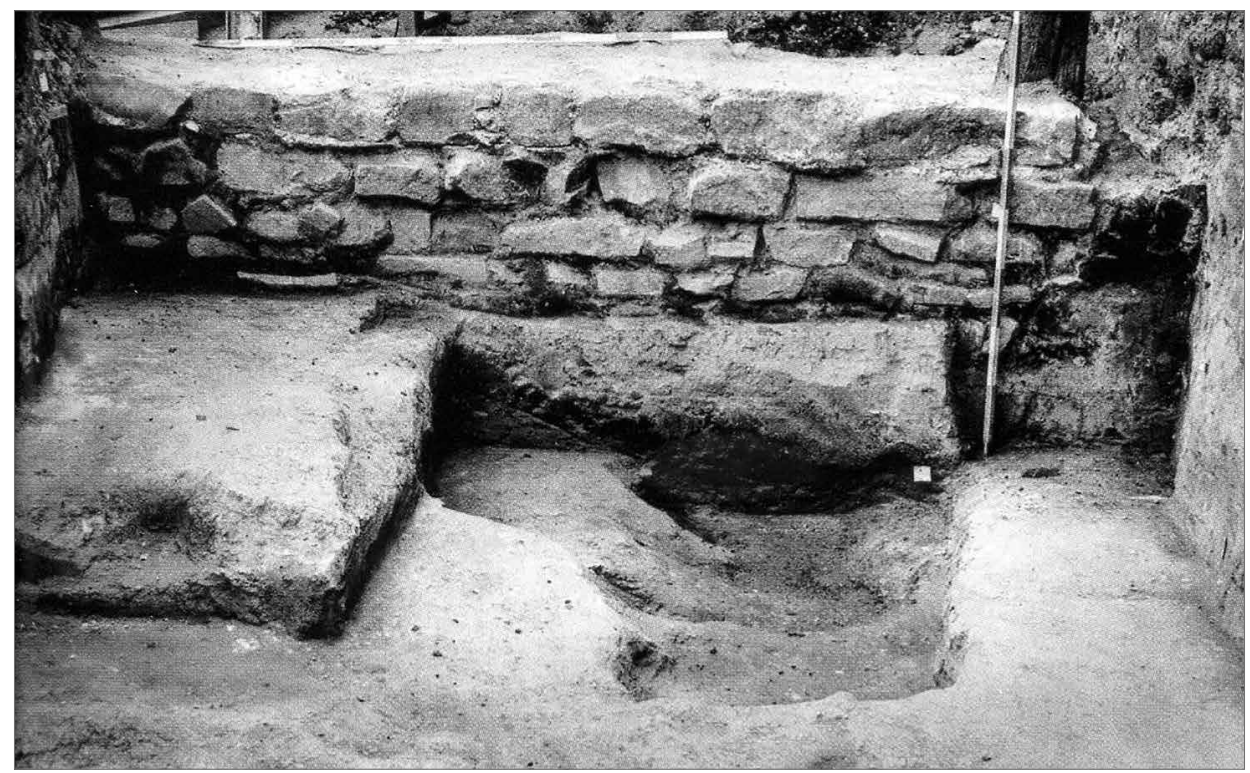

Obr. 16. Část zdiva nedostavěné pozdně velkomoravské stavby na ulici Hradební (SPT Telecom). Podle Škrdla-VaškovýchGaluška 2007, 55. Foto R. Procházka.

Abb. 16. Teil eines Mauerwerks eines nicht fertiggebauten spätgroßmährischen Bauwerks in der Hradební-Str. (SPT Telecom). Nach Škrdla-Vaškových-Galuška 2007, 55. Foto R. Procházka.

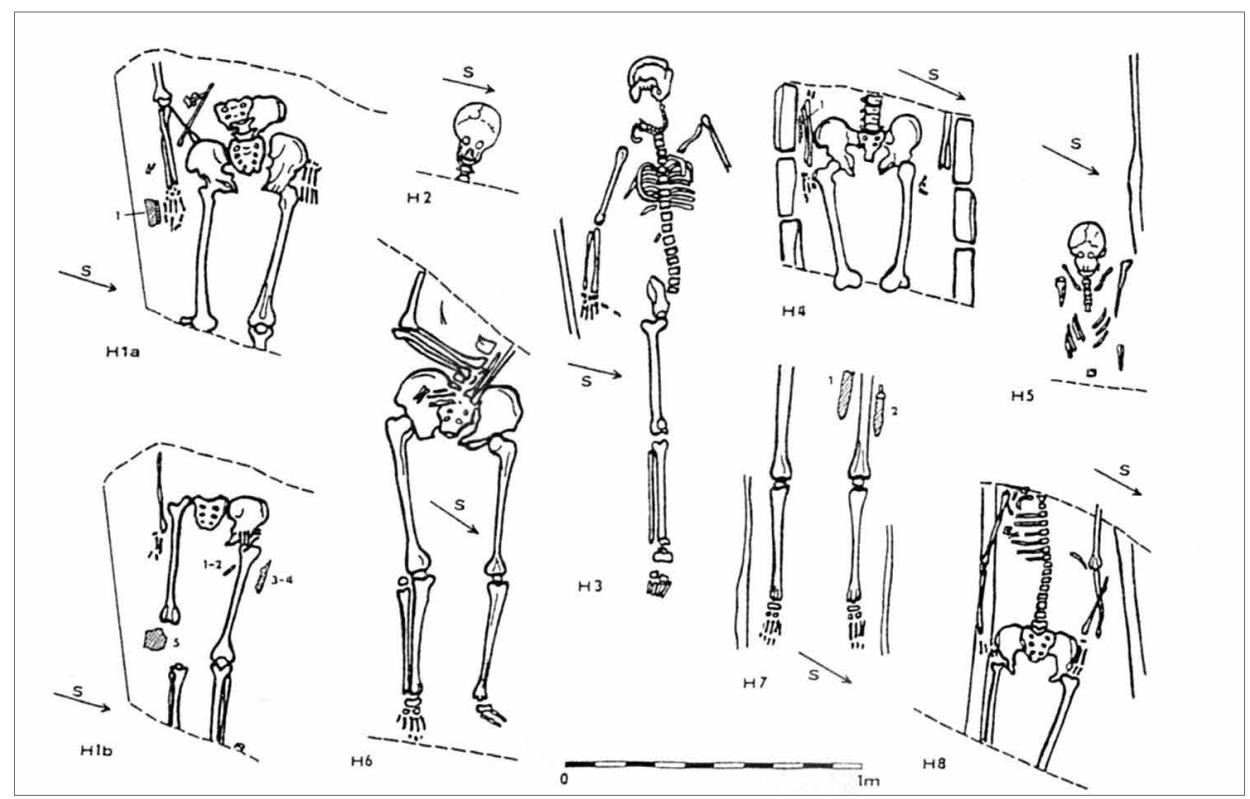

Obr. 17. Dokumentace kostrových hrobů 1a-8 středohradištního stáří zachycených záchranným výzkumem v místní části Uherského Hradiště Rybárnách, Luční ulice, 1986. Archeologický výzkum probíhal ve složité nálezové situaci komplikované zástavbou rodinných domků. Podle Snášil-Krut’a-Stloukal 1994, 121, obr. 6.

Abb. 17. Dokumentation der in Uherské Hradiště im Stadtteil Rybárny in der Straße Luční 1986 bei einer Rettungsgrabung entdeckten Skelettgräber 1a-8. Die archäologische Grabung erfolgte in der komplizierten Fundsituation einer komplizierten Bebauung mit Familienhäusern. Nach Snášil-Krut’a-Stloukal 1994, 121, Abb. 6. 
o přírodním prostředí také výrazně přispěl k poznání dynamicky se měnící koexistence lidského a přírodního faktoru na tzv. ostrově sv. Jiří. Nálezem zdiva i objektů souvisejících s přechodem přes řeku se významným způsobem vyjádřil $\mathrm{k}$ topografickému vývoji v této části města během 9. století (Frolíková-Kaliszová 2001; 115-121; 1990, 62-63; Kaliszová 1990, 62-63; 1991, 50-51; Procházka-Snášil 1983, 62-64; Snášil-Novotný 1985, 71; Snášil-Procházka 1981a, 53-54; 1981b, 18, 28-29; 1982, 52-55; 1984, 63).

Středohradištní vrstvy a objekty jsou známy i z dalších poloh v centru dnešního historického jádra Uherského Hradiště. Na jihu je stř̌edohradištní osídlení vymezeno prostorem nádvoří jižního traktu bývalé jezuitské koleje tzv. Reduty (Beroušek-Kováčik 1998, 63-76) a parkem u budovy jezuitského kláštera (Snášil-Procházka 1981b, 18; Procházka-Snášil 1983, 63; srovnej obr. 13:9, 10). Na severovýchodě tvoří periferii velkomoravského osídlení nároží ulic Hradební a Krátká (Čižmář-Geislerová-Unger 2000, 234-237; srovnej obr. 13:11). Intenzivní osídlení bylo zachyceno na severu na místě rajského dvora františkánského kláštera (Snášil 1991-1992, 117-129; obr. 13:12) a na severozápadě na nádvoří Galerie Slováckého muzea (obr. 13:14; SnášilProcházka 1981a, 53-54; 1981b, 18).

Z prostoru kašny na Mariánském náměstí víme o středohradištních souvrstvích (obr. 13:13), která však byla odbagrována ještě před započetím výzkumu (Pavelčík 1996). Poněkud nejasná a moderními datovacími prostředky neověřená zůstává situace na jihu v místech bývalého pivovaru (ulice Hradební; obr. 13:18), kde již na přelomu let 1979 a 1980 byla identifikována konstrukce palisád a komor z dubových pilotů, jejichž stáří bylo pomocí dat $C^{14}$ určeno na $650 \pm 130$ (Snášil 1981, 490-491; 1986, 35; Snášil-Procházka 1981a, 53-54; 1981b, 18, 26-28; 1982, 53).

Z novějších výzkumů je třeba zmínit nedestruktivní geofyzikální zaměření, kterého bylo v exponovaném historickém jádru města využito v roce 2017 k interpretaci destrukce kamenného objektu (obr. 13:7) patrně středohradištního stáří (velkomoravský horizont osídlení), zachycené v roce 2006. Interpretace objektu však stále není uspokojivá, prozatím se lze vyjádřit, že objekt patrně souvisel s tokem zde probíhající vodoteče (kamenný sypaný základ nějaké lehčí stavby?; Menoušková-Dresler-Pelikán 2019). Geofyzikálním průzkumem se podařilo zjistit, že archeologicky zachycený úsek představuje pouze část objektu (destrukce), který pokračuje severním, ale především jižním směrem pod stávající městskou zástavbu.

$\mathrm{V}$ roce 2017 proběhl pod vedením

J. Bartíka ${ }^{11}$ ze Slováckého muzea záchranný výzkum ve sklepních prostorách Základní umělecké školy na nároží ulice Františkánské a Mariánského náměstí (číslo popisné 125; obr. 13:16), který se mimo jiné vyjádřil i k dynamicky se měnící topografické situaci v této části města v 8.-9. století (Bartík-Chrástek 2018, 276-277). Z výzkumu nadzemního domu raně středověkého stáŕí bylo získáno také dobové falzum arabského dirhamu z let 775-785 (obr. 18). Ten, stejně jako další předměty, indikuje přítomnost vyšších sociálních vrstev na lokalitě. $\mathrm{S}$ přítomností velkomoravské nobility souvisí, at' už přímo, či nepřímo i předměty nalezené nedaleko, na Mariánském náměstí číslo popisné 69 (obr. 13:17). Výzkum z let 1980-1986 zde zachytil jak předvelkomoravský, tak velkomoravský horizont
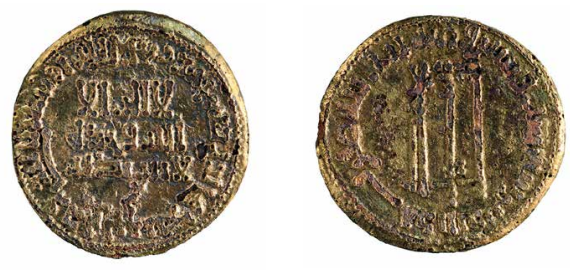

Obr. 18. Líc a rub dobového falza arabského dirhamu z let 775-785. Záchranný výzkum ve sklepních prostorách Základní umělecké školy na nároží ulice Františkánské a Mariánského náměstí, Uherské Hradiště, 2017. Foto L. Chvalkovský.

Abb. 18. Vorder- und Rückseite einer zeitgenössischen Fälschung eines arabischen Dirhams aus den Jahren 775-785. Rettungsgrabung in den Kellerräumen der Kunstgrundschule an der Ecke Františkánská-Str. und Marienplatz, Uherské Hradiště, 2017. Foto L. Chvalkovský.

11 Nálezová zpráva nebyla v době odevzdání tohoto textu ještě zpracovaná. Za informace k výzkumu a možnost publikovat falzum arabské mince děkuji autorovi výzkumu. 
reprezentovaný četnými nálezy (včetně např. keramiky antických tvarů). K předvelkomoravskému horizontu se hlásí především tři jednodílné lité bronzové ostruhy s háčky, z nichž jedna je neopracovaným výlitkem. Neméně významný je nález pozlaceného litého prolamovaného nákončí a bronzového kování opasku (Snášil-Novotný 1985, 71-72).

\section{Sedmdesátka a jak dál}

Připomínka stoletého výročí založení Archeologického ústavu, která zavdala příčinu i k tomuto bilančnímu př́spěvku, je samozřejmě nejen důvodem vzpomínat a ohlížet se zpět, ale také hodnotit, rekapitulovat a pohlížet do budoucna. A to i v př́ípadě středohradištní staroměstsko-uherskohradišt'ské aglomerace. Extenzivní a v mnohém objevné a přelomové výzkumy z přelomu 40. a 50. a z 60. let položily základ poznání středohradištní staroměstsko-uherskohradišt'ské aglomerace. Nelze však popř́t, že byly provedeny s ohledem na dobové možnosti a znalosti. V tomto kontextu je třeba pohlížet i na interpretaci a prvotní publikaci objevených pozůstatků velkomoravských staveb a $\mathrm{k}$ nim náležejících pohřebišt'. Právě jejich poznávání bylo charakterizováno často urputnými diskusemi na téma typologie, původu a datování. V této souvislosti lze připomenout i vášnivé a neutuchající diskuse odborníků ohledně typologie a stavebního vývoje velkomoravských kostelů (srovnej Poláček 2014, 87-91) a jako př́iklad uvést kostel v Modré u Velehradu (např. Cibulka 1958; Hrubý 1965b, 198-202). V řadě z uvedených výzkumů a interpretací lokalit jsme se ale od jejich ucelené publikace (např. Hrubý 1955; 1965b) zásadním způsobem dál neposunuli. Postrádáme kritické revizní zhodnocení těchto výzkumů s využitím nových často nedestruktivních metod umožňujících lepší vyhodnocení materiálu v kontextu s novými poznatky.

Takové postupy naznačují např́iklad některé výzkumy v historickém jádru dnešního Uherského Hradiště (srovnej např. Bartík-Chrástek 2018; Dresler-Vágner 2013). Možnosti zapojení prírodovědných oborů ukazuje mezi jinými výživová studie z prostředí Mikulčic (Látková 2019). Dalším prŕíladem mohou být některé projekty, které v souvislosti s vyhodnocením nálezově bohatých středohradištních pohřebišt' či jednotlivých hrobů provádí Archeologický ústav v Praze. Jde např́klad o analýzu kosterních ostatků s cílem rekonstruovat výživu zemřelých s pomocí analýzy stabilních izotopů dusíku a uhlíku, dále o ověření rezidenční mobility pomocí analýzy izotopů stroncia a radiouhlíkového datování, popř́ípadě o analýzu historické DNA umožňující zařazení kosterních pozůstatků do rodových linií, popřípadě určení příbuzenských vztahů mezi zkoumanými jedinci (srovnej např. Bravermanová a kol. 2018, 260-293). Zmíněné analýzy by mohly významným způsobem ovlivnit interpretaci některých bohatých hrobů staroměstského pohřebiště „Na Valách“ či uherskohradišt'ských „Sadů“, právě s potenciálem ukázat na případnou mobilitu či (specifické) stravovací zvyklosti, nebo je popřít. Jestliže jsou právě uherskohradišt'ské „Sady“ dávány často do souvislosti s vlivy z byzantské kulturní sféry a jde o jedno z míst, o němž se uvažuje v souvislosti s původním uložením ostatků sv. Metoděje (srovnej např. Galuška 1996; 2014, 182), byly by zde takovéto analýzy nanejvýše žádoucí. A to samozřejmě s vědomím, že tyto, ale i řada dalších přírodovědných a geofyzikálních analýz jsou pro archeologii ,jen“ pomocnými metodami poskytujícími nicméně solidní zázemí pro další archeologické interpretace a výzkumy s cílem získat co nejkomplexnější pohled na tu kterou lokalitu.

Jiný, finančně méně nákladný směr, jímž je možné se ubírat, ukazuje výzkum technologie výroby některých šperků v Lumbeho zahradě Pražského hradu (Šejvlová-Ottenwelter-Frolík 2014, 248-259) a s tím související metalografické analýzy. Ty vedle lepšího poznání technologie výroby umožňují zjistit i přibližný čas nutný k výrobě takovýchto špeků. Právě srovnání časové náročnosti ukazuje, že exkluzivní náušnice či gombíky nalézané v bohatých středohradištních hrobech byly po výrobní stránce náročné nejen na zručnost a zkušenosti šperkaře, ale rovněž na jeho čas, což se samozrrejmě odráželo i v konečné ceně výrobku dostupného patrně jen elitní vrstvě obyvatel.

Kritický přístup, revize starších výzkumů (viz např́iklad revizní výzkumy souboru mikulčických kostelů; k tomu souhrnně např. Poláček 2014, 87-91) a analytické zpracování s využitím 
řady především prŕírodovědných a geofyzikálních metod jou však cesty, kudy by se mělo ubírat a ubírá se i bádání v rámci nivní, rríčními rameny chráněné polohy tzv. ostrova sv. Jiří, která stála v oněch objevitelských letech stranou převratných a velkých výzkumů staroměstsko-uherskohradišt'ské aglomerace (podrobněji k tomu viz příspěvek D. Frolíkové-Kaliszové 2020, 785-807). Dnešní historické jádro Uherského Hradiště je ale na rozdíl od většiny ostatních dotčených poloh aglomerace hustě zastavěno novodobou infrastrukturou městského charakteru a o to bylo a je jeho poznávání složitější. Jde přitom o významné středohradištní centrum 8. a 9. století s řadou dokladů raně středověkých kamenných architektur. Přestože mají naše znalosti o raně středověké sídelní struktuře na levobřeží řeky Moravy stále neúplný charakter, daří se je s využitím nedestruktivních geofyzikálních metod prospekce, ale i díky záchranným výzkumům posledních let zpřesňovat, a dokumentovat raně středověké sídelní aktivity pod hustou městskou zástavbou, a tak poněkud „rehabilitovat“ postavení tzv. ostrova sv. Jiří v rámci staroměstsko-uherskohradišt'ské aglomerace.

\section{Prameny a literatura}

BARTÍK, J.-CHRÁSTEK, T., 2018: Uherské Hradiště. Mariánské náměstí, PV 59, č. 2, 276-277.

BEROUŠEK, J.-KOVÁČIK, P., 1998: Př́íspěvek k historické topografii Uherského Hradiště, SPFFBU M 3, 63-76.

BRAVERMANOVÁ, M. a kol., 2018: Bravermanová, M.-Dobisíková, M.-Frolík, J.-Kaupová, S.-Stránská, P.-Světlík, I.-Vaněk, D.-Velímský, P.-Votrubová, J., Nové poznatky o ostatcích z hrobů K1 a K2 z rotundy sv. Víta na Pražském hradě, AR LXX, 260-293.

CDB V/1: Codex diplomaticus et epistolaris regni Bohemiae, tom. V, fasc. 1 (1253-1266) (Šebánek, J.-Dušková, S., edd.). Praha 1974.

CIBULKA, J., 1958: Velkomoravský kostel v Modré u Velehradu a začátky křest’anství na Moravě. Praha.

ČIŽMÁŘ, M.-GEISLEROVÁ, K.-UNGER, J., edd., 2000: Výzkumy - Ausgrabungen 1993-1998. Brno.

DRESLER, P. a kol., 2010: Dresler, P.-Humlová, B.-Macháček, J.-Rybníček, M.-Škojec, J.-Vrbová-Dvorská, J., Dendrochronologické datování raně středověké aglomerace na Pohansku u Břeclavi. In: Zaměřeno na středověk. Zdeňkovi Měřínskému k 60. narozeninám (Ungerman, Š.-Přichystalová, R., edd.), 112-138, 750-752. Brno.

DRESLER, P.-VÁGNER, M., 2013: Geofyzikální průzkum Masarykova náměstí a lokalizace kostela sv. Jiří, Slovácko LIV (2012), 155-164.

FROLÍKOVÁ-KALISZOVÁ, D., 1990: Výsledky archeologického výzkumu v Uherském Hradišti v letech 1987-1988, Slovácko XXXI, 147-163.

-2001: Výzkum na Otakarově ulici v Uherském Hradišti - některé otázky vývoje velkomoravského hradiska. In: Velká Morava mezi východem a západem. Sborník příspěvků z mezinárodní konference. Spisy AÚ AV ČR Brno 17 (Galuška, L.-Kouřil, P.-Měřínský, Z., edd.), 115-121. Brno.

-2020: Archeologie o Uherském Hradišti v době velkomoravské - výzkumy, lidé, povodně (40 let od zahájení plošných výzkumů), AH 45, 785-807.

GALUŠKA, L., 1996: Uherské Hradiště-Sady. Křestanské centrum Říše velkomoravské. Brno.

- 2001: Staroměstsko-uherskohradištská aglomerace - vývoj osídlení a přírodní poměry v 6.-10. století. In: Velká Morava mezi východem a západem. Sborník příspěvků z mezinárodní konference (Galuška, L.Kouřil, P.-Měřínský, Z., edd.), 124-137. Brno.

- 2014: Staré Město - Uherské Hradiště. In: Velká Morava a počátky křestanství (Kouřil, P., ed.), 178-183. Brno.

- v tisku: Devítky ve významných datech objevů velkomoravské architektury na Uherskohradištsku, Slovácko LXI (2019).

GALUŠKA, L. a kol., 2019: Galuška, L.-Hochmanová-Vávrová, V.-Hrubý, V.-Mitáček, J., Uherské Hradiště-Sady. 500 let křest'anství ve střední Evropě. I. katalog pohřebiště. Brno.

GALUŠKA, L.-VAŠKOVÝCH, M., 2006: Archeologický skanzen v Modré u Velehradu: velkomoravské opevněné sídliště středního Pomoraví. Modrá. 
GALUŠKA, L.-VAŠKOVÝCH, M.-MENOUŠKOVÁ, D., 2016: Památník Velké Moravy. Staré Město, Uherské Hradiště, Modrá, sv. Kliment u Osvětiman. 2. rozšířené vydání. Uherské Hradiště.

HANÁK, K., 1932: Po stopách zašlých hradisk na půdě staroslovanského Velehradu, Sborník Velehradský NŘ 3, 5-9.

- 1933: Výroční zpráva o činnosti spolku, Sborník velehradský NŘ 4, 4-6.

HRUBÝ, V., 1955: Staré Město. Velkomoravské pohřebiště „Na Valách“. Praha.

- 1959: Velkomoravské hradisko sv. Klimenta u Osvětiman, ČMMZ 44, 19-59, 65-70.

- 1965a: Byl nalezen hrob věrozvěsta Metoděje? In: Almanach Velká Morava. Moravské muzeum Brno, 147-149. Brno.

- 1965b: Staré Město. Velkomoravský Velehrad. Praha.

CHRÁSTEK, T., 2010: Archeologický výzkum na katastru obce Modrá-Hrubý díl v roce 2009, Slovácko LI (2009), 167-184.

KALISZOVÁ, D., 1990: 8. sezóna výzkumu na Otakarově ulici v Uherském Hradišti (okr. Uherské Hradiště), PV 1987, 62-63.

- 1991: 9. sezóna výzkumu na Otakarově ulici v Uherském Hradišti (okr. Uherské Hradiště), PV 1988, 50-51.

KOHOUTEK, J.-PROCHÁZKA, R., 1993: Uherské Hradiště, Hradební ul. - Růžová ul. (SPT Telecom). Rukopis nálezové zprávy 581/98. Uloženo v archivu archeologického oddělení Slováckého muzea v Uherském Hradišti.

- 1997: Uherské Hradiště (okr. Uherské Hradiště), PV 1993-1994, 251-254.

KONEČNÝ, L.-KUDĚLKA, Z.-MALINOVÁ, R.-SAMEK, B., 1977/1978: Výzkum románské architektury na Moravě I, SPFFBU F 21/22, 39-42.

LÁTKOVÁ, M., 2019: Rostliny a výživa velkomoravských Mikulčic. Brno.

MACHÁČEK, J., 2014: Pohansko u Břeclavi. In: Velká Morava a počátky křest’anství (Kouřil, P., ed.), 184-187. Brno.

MACHÁČEK, J. a kol., 2007: Macháček, J.-Doláková, N.-Dresler, P.-Havlíček, P.-Hladilová, Š.-Přichystal, A.-Roszková, A.-Smolíková, L., Raně středověké centrum na Pohansku u Břeclavi a jeho přírodní prostředí, AR LIX, 278-314.

MENOUŠKOVÁ, D., 2001: Hradisko sv. Klimenta. In: Konference Pohansko 1999: 40 let od zahájení výzkumu slovanského hradiska Břeclav-Pohansko. Archaeologia mediaevalis Moravica et Silesiana I/2000 (Měřínský, Z., ed.), 159-184. Brno.

- 2013: Kostel a kaple sv. Jiří v Uherském Hradišti, Slovácko LIV (2012), 141-154.

MENOUŠKOVÁ, D.-DRESLER, P.-PELIKÁN, O., 2019: K průběhu a rozsahu destrukce kamenného objektu z Uherského Hradiště, Protzkarovy ulice, Slovácko LX (2018), 81-94.

NEVĚǨIL, J., 1940: Archeologické vykopávky na Velehradě na podzim r. 1911, Sborník velehradský 11, 76-80.

ONDRUŠ, V., 1965: Velkomoravský kostel na hradisku sv. Klimenta. In: Almanach Velká Morava. Moravské muzeum Brno, 112-115. Brno.

PAVELČÍK, J., 1996: Uherské Hradiště - Mariánské náměstí, kašna. Nálezová zprava 409/96. Archiv archeologického oddělení Slováckého muzea v Uherském Hradišti.

POLÁČEK, L., 2014: Velkomoravská církevní architektura. In: Velká Morava a počátky křest’anství (Kouřil, P., ed.), 87-91. Brno.

POLÁČEK, L.-MAŘÍKOVÁ-KUBKOVÁ, J., edd., 2010: Frühmittelaterliche Kirchen als archäologische und historische Quelle. Internationale Tagungen in Mikulčice. Band VIII. Archäologisches Institut der Akademie der Wissenschaften der Tschechischen Republik, v. v. i. Brno.

POULÍK, J., 1950: Objev druhého kostela ve Starém Městě, AR II, 12-21.

PROCHÁZKA, R.-SNÁŠIL, R., 1983: Výzkumy v Uherském Hradišti v roce 1981 (okr. Uherské Hradiště), PV 1981, 62-64.

SKLENÁŘ, K., 1977: Slepé uličky archeologie. Praha.

SNÁŠIL, R., 1981: Osídlení území města v pravěku a časné době dějinné. Nové archeologické výzkumy. In: Uherské Hradiště. Dějiny města, 39-79, 488-498. Brno.

- 1986: Výsledky archeologických výzkumů Slováckého muzea za období 1981-1985, Slovácko XXVIII, $33-46$. 
- 1991-1992: Zpráva o archeologických výzkumech a př́írůstcích Slováckého muzea v roce 1991, Slovácko XXXIII-XXXIV, 117-129.

- 2001: „Capella Morauorum“ a „templum sub titulo s. Clementis“, Slovácko XLII (2000), 177-194.

SNÁŠIL, R.-KRUŤA, T.-STLOUKAL, M., 1994: Výzkum v Uh. Hradišti-Rybárnách v roce 1986, část I. materiály, Slovácko XXXV (1993), 115-147.

- 1995: Výzkum v Uh. Hradišti-Rybárnách v roce 1986, část II. - interpretace (petrografie, antropologie), Slovácko XXXVI (1994), 73-78.

SNÁŠIL, R.-NOVOTNÝ, J., 1985: Výzkumy v Uherském Hradišti v roce 1983 (okr. Uherské Hradiště), PV 1983, 71-74.

SNÁŠIL, R.-PROCHÁZKA, R., 1981a: Archeologické výzkumy v Uherském Hradišti v roce 1979 (okr. Uherské Hradiště), PV 1979, 53-54.

- 1981b: Př́íspěvek k poznání velkomoravského střediska severní části dolnomoravského úvalu, Slovácko XXIII, 9-58.

- 1982: Výzkumy v Uherském Hradišti v roce 1980 (okr. Uherské Hradiště), PV 1980, 52-55.

- 1984: Výzkumy v Uherském Hradišti v roce 1982 (okr. Uherské Hradiště), PV 1982, 63-65.

ŠEJVLOVÁ, L.-OTTENWELTER, E.-FROLÍK, J., 2014: Zhotovení repliky stříbrných gombíků z raně středověkého pohřebiště v Lumbeho zahradě na Pražském hradě - Herstellung von Repliken von silberknöpfen vom frühmittelalterlichen Gräberfeld im lumbe-Garten auf der prager burg, AH 39, 248-259.

ŠKRDLA, P.-VAŠKOVÝCH, M.-GALUŠKA L., 2007: Na dávné jantarové stezce. In: Uherské Hradiště královské město na řece Moravě, 31-58. Uherské Hradiště.

UDPHUAY, S.-PAUL, V. L.-EVERETT, M. E.-WARDEN, R. B., 2010: Ground-penetrating radar imaging of twelfth century Romanesque foundations beneath the thirteenth century Gothic abbey church of Valmagne, France, Archaeological Prospection 17, 199. https://oi.org/10.1002/arp.383

VAŠKOVÝCH, M., 2014: Modrá (okr. Uherské Hradiště), PV 55, 237-238.

VITULA, P., 1997: Uherské Hradiště (okr. Uherské Hradiště), PV 1993-1994, 254-256.

WITTEN, A. J., 2006: Handbook of Geophysics and Archaeology. London.

ZELNITIUS, A., 1933: Stručný přehled archeologie a archeologického výzkumu v okresu Uhersko-hradišt'ském, Sborník velehradský NŘ 10, 14-18.

- 1946: Slovíčko o velkomoravském Velehradě, Sborník velehradský NŘ 14, 95-110.

\section{Zusammenfassung}

Siebzig Jahre archäologische Grabungen an mittelburgwallzeitlichen Fundstätten in der Region Uherské Hradiště und der gegenwärtige Kenntnisstand zur sog. St. Georgsinsel

Die 1949 in Staré Město bei Uherské Hradiště gemachten Entdeckungen der Überreste zweier mittelburgwallzeitlicher Kirchen und die im Zusammenhang damit erfolgten Grabungen wurden $\mathrm{zu}$ bedeutenden Meilensteinen, die für lange Zeit die Richtung der Archäologie der Mittelburgwallzeit, aber auch von einer Reihe von Archäologen beeinflusst hatten. Hinter der ersten dieser an der Fundstätte Staré Město „Na Valách“ gemachten Entdeckungen stand der Lehrer und zunächst amateurhafte, schließlich dann professionelle Archäologe Wilém Hrubý, der mit einer Grabung auf dem ausgedehnten und an Funden reichen Gräberfeld an die Tätigkeit des Amateurarchäologen A. Zelnitius anknüpfte. Die Entdeckung des Fundamentnegativs einer einschiffigen Saalkirche aus der Mittelburgwallzeit war außergewöhnlich. Im Rahmen der gesamten damaligen Tschechoslowakei waren dies die überhaupt ersten fachgerecht untersuchten Überreste des Fundaments einer mittelburgwallzeitlichen Kirche. Noch im Herbst desselben Jahres (1949) wurde dann unter etwas dramatischen Umständen das flache Fundamentnegativ eines weiteren großmährischen Bauwerks - der Kirche „Na Špitálkách“ in Staré Město - durch eine Grabung von Josef Poulík vom Staatlichen archäologischen Institut in Brno vor der Abtragung gerettet. Nichtsdestoweniger hatte die Entdeckung der Fundamente großmährischer Kirchenbauten in der 
Region Uherské Hradiště im Jahr 1911 bereits ihr Vorspiel, als Jan Nevěřil, ein Professor der Theologischen Fakultät in Olmütz, das Fundament der kleinen Kirche in Modrá bei Velehrad mit dem ähnlichen Grundriss der St. Katharinenkirche in Tetín verglich und es in die Zeit nach Ankunft der Kyrillo-Methodischen Missionierung datierte. Noch tiefer reichen die Anfänge amateurhafter Aktivitäten an der Burgstätte des Hl. Clemens bei Osvětimany, die immer noch stark mit der Kyrillo-Methodischen Tradition in Verbindung gebracht wird und einem nicht nachlassenden Interesse der Öffentlichkeit begegnet. Ähnlich wie im Falle der Burgstätte des H1. Clemens bei Osvětimany fehlt auch bei weiteren mittelburgwallzeitlichen Fundstätten der Siedlungsagglomeration Staré Město - Uherské Hradiště eine kritische, bzw. zumindest moderne Quellenbearbeitung unter Heranziehung der Möglichkeiten, die etwa naturwissenschaftliche Methoden bieten. An der Entdeckung der Mauerüberreste zweier mittelburgwallzeitlicher Kirchen in Staré Město wie auch an den anschließend in der Region Uherské Hradiště erfolgten archäologischen Grabungen der fünfziger bis achtziger Jahre des 20. Jahrhunderts und ihrer Interpretation hatten sowohl die politischen Verhältnisse und Präferenzen der gegebenen Zeit, als auch die persönlichen Aversionen einiger Forscher einen beträchtlichen Anteil. Die extensiven und in vielerlei Hinsicht einzigartigen Freilegungen in Starè Město haben eine außergewöhnliche Aufmerksamkeit auf sich gezogen, was sich leider unseligerweise auf die Erforschung der mittelburgwallzeitlichen Anfänge einer anderen, sehr nahe gelegenen Fundstätte ausgewirkt hat: auf die sog. St. Georgs-Insel, also auf den historischen Stadtkern des heutigen Uherské Hradiště. Die Konservierung des Zustandes, in dem diese und weitere an der Wende der vierziger und fünfziger sowie sechziger Jahre entdeckten und erstmals publizierten mittelburgwallzeitliche Fundstätten waren, wird auch durch die Tatsache aussagekräftig illustriert, dass es mit Ausnahme von Uherské Hradiště-Sady und teilweise der Fundstätte Modrá „Na Díle“ bei keiner von ihnen zu einer zusammenfassenden oder revidierenden Bearbeitung kam. Die extensiven und in vielerei Hinsicht entdeckerischen und bahnbrechenden Grabungen von der Wende der vierziger und fünfziger und sechziger Jahre haben für die Erforschung der mittelburgwallzeitlichen Siedlungsagglomeration Staré Město - Uherské Hradiště den Grundstein gelegt. Es lässt sich jedoch nicht leugnen, dass sie unter Berücksichtigung der damaligen Möglichkeiten und Kenntnisse durchgeführt wurden. In diesem Kontext muss man demnach auch die Interpretation und die ersten Veröffentlichungen der entdeckten Überreste großmährischer Bauten und der dazugehörigen Gräberfelder sehen. Gerade für ihre Analyse waren häufig heftige Diskussionen über die Themen Typologie, Ursprung und Datierung charakteristisch. Bei einer Reihe der genannten Grabungen und Interpretationen der Fundstätten sind wir aber seit ihren umfassenden Veröffentlichungen (z.B. Hrubý 1955; 1965b) keinen wesentlichen Schritt weitergekommen. Wir vermissen eine kritische revidierende Bewertung dieser Grabungen unter Heranziehung neuer, häufig zerstörungsfreier Methoden, die eine bessere Auswertung des Materials im Zusammenhang mit neuen Erkenntnissen ermöglichen.

Einen der Wege, der weiter beschritten werden sollte, zeigt beispielsweise die Untersuchung von Skelettüberresten mit dem Ziel, die Ernährung der Verstorbenen anhand einer Analyse der stabilen Stickstoff- und Kohlenstoffisotope zu rekonstruieren, oder die Feststellung der Residenzmobilität anhand einer Strontiumisotopenanalyse und Radiokohlenstoffdatierung, ggf. einer Analyse der historischen DNA (vgl. etwa Bravermanová et al. 2018, 260-293). Eine andere, kostengünstigere Richtung ist die Untersuchung der Herstellungsverfahren von einigen Schmuckstücken (z.B. im Lumbe-Garten auf der Prager Burg von Šejvlová-Ottenwelter-Frolík 2014, 248-259) und die damit zusammenhängenden metallographischen Analysen. Sie ermöglichen es, neben genaueren Kenntnissen über die Herstellungsverfahren auch die ungefähre Zeit zu ermitteln, die zur Herstellung von solchem Schmuck benötigt wurde. Gerade ein Vergleich des jeweiligen Zeitaufwands zeigt auf, dass die in reichen mittelburgwallzeitlichen Gräbern gefundenen exklusiven Ohrringe oder Knöpfe bezüglich ihrer Herstellung nicht nur hinsichtlich Fähigkeit und Erfahrung der Schmuckmacher anspruchsvoll waren, sondern auch viel Zeit beanspruchten, was sich selbstverständlich auch im Endpreis des offenbar nur für eine elitäre Schicht der Bewohner erschwinglichen Produkts niederschlug. 
Eine kritische Vorgehensweise und analytische Bearbeitung unter Heranziehung einer Reihe von vornehmlich naturwissenschaftlichen Methoden sind jedoch Wege, die auch im Rahmen der von Flussarmen geschützten Auenlage der sog. St. Georgs-Insel beschritten werden sollten, die in jenen entdeckerischen Jahren im Abseits der bahnbrechenden, in der Siedlungsagglomeration Staré Město-Uherské Hradiště durchgeführten großen Grabungen standen. Der heutige historische Stadtkern von Uherské Hradiště ist jedoch im Unterschied zu den meisten übrigen betroffenen Lagen der Agglomeration dicht bebaut mit neuzeitlicher Infrastruktur städtischen Charakters, weswegen ihre Erforschung umso komplizierter ist. Dabei handelt es sich um ein bedeutendes mittelburgwallzeitliches Zentrum des 8. und 9. Jahrhunderts mit einer Reihe von Belegen für die frühmittelalterliche Steinarchitektur. Obwohl unsere Kenntnisse über die frühmittelalterliche Siedlungsstruktur am linken Ufer der March immer noch einen unvollständigen Charakter aufweisen, gelingt es, sie unter Heranziehung zerstörungsfreier geophysikalischer Prospektionsmethoden, aber auch Dank der in den letzten Jahren erfolgten Rettungsgrabungen zu präsizieren und die frühmittelalterliche Siedlungsaktivitäten unter der dichten Stadtbebauung auf diese Weise zu dokumentieren.

Mgr. Dana Menoušková, Slovácké muzeum v Uherském Hradišti, p. o., Smetanovy sady 179, 68601 Uherské Hradiště, Česká republika, dana.menouskova@slovackemuzeum.cz 
